\title{
Kinematic reworking and exhumation within the convergent Alpine Orogen
}

\author{
S.M. Reddy ${ }^{\mathrm{a}, *}$, J. Wheeler ${ }^{\mathrm{b}}$, R.W.H. Butler ${ }^{\mathrm{c}}$, R.A. Cliff ${ }^{\mathrm{c}}$, S. \\ Freeman $^{c}$, S. Inger ${ }^{\mathrm{d}}$, C. Pickles ${ }^{\mathrm{d}}$, \& S.P. Kelley ${ }^{\mathrm{e}}$ \\ ${ }^{a}$ Tectonics Special Research Centre, Dept of Applied Geology, Curtin University of Technology, GPO Box \\ U1987, Perth, WA 6845, Australia. \\ ${ }^{b}$ Department of Earth Sciences, The University of Liverpool, Liverpool, L69 3BX, UK. \\ ${ }^{c}$ School of Earth Sciences, The University of Leeds, Leeds, LS2 9JT, UK. \\ ${ }^{d}$ CASP, The University of Cambridge, Cambridge, UK. \\ ${ }^{e}$ Department of Earth Sciences, The Open University, Milton Keynes, MK7 6AA, UK.
}

Key Words: Western Alps, $\mathrm{Rb} / \mathrm{Sr},{ }^{40} \mathrm{Ar} /{ }^{39} \mathrm{Ar}$, laserprobe, tectonics, eclogite, shear zone, extension.

\footnotetext{
* Corresponding author. Tel.:+61-8-9266-4371; fax: +61-8-9266-3153

E-mail address: S.Reddy@curtin.edu.au (S. Reddy)
} 


\begin{abstract}
Kinematic data from the internal zones of the Western Alps indicate both top-to-SE and top-to-NW shearing during syn-kinematic greenschist facies recrystallisation. $\mathrm{Rb} / \mathrm{Sr}$ data from white micas from different kinematic domains record a range of ages that do not represent closure through a single thermal event but reflect the variable timing of syn-kinematic mica recrystallisation at temperatures between $300-450^{\circ} \mathrm{C}$. The data indicate an initial phase of accretion and foreland-directed thrusting at c. 60 Ma followed by almost complete reworking of thrust-related deformation by SE-directed shearing. This deformation is localised within oceanic units of the Combin Zone and the base of the overlying Austroalpine basement and forms a regional scale shear zone that can be traced for almost $50 \mathrm{~km}$ perpendicular to strike. The timing of deformation in this shear zone spans $9 \mathrm{Ma}$ from 45-36 Ma. The SE-directed shear leads to local structures that cut upwards in the transport direction with respect to tectonic stratigraphy, and such structures have been interpreted in the past as backthrusts in response to ongoing Alpine convergence. However, on a regional scale the top-to-SE deformation is related to crustal extension, not shortening, and is coincident with exhumation of eclogites in its footwall. During this extension phase, deformation within the shear zone migrated both spatially and temporally giving rise to domains of older shear zone fabrics intercalated with zones of localised reworking. Top-NW kinematics preserved within the Combin Zone show a range of ages. The oldest (48 Ma) may reflect the final stages of emplacement of
\end{abstract} Austroalpine Units above Piemonte oceanic rocks prior to the onset of extension. However, much of the top-toNW deformation took place over the period of extension and may reflect either continuing or episodic convergence or tectonic thinning of the shear zone.

${ }^{40} \mathrm{Ar} /{ }^{39} \mathrm{Ar}$ data from the region are complicated due to the widespread occurrence of excess ${ }^{40} \mathrm{Ar}$ in eclogite facies micas and partial Ar loss during Alpine heating. Reliable ages from both eclogite and greenschist facies micas indicate cooling ages in different tectonic units of between 32-40 Ma. These ages are slightly younger than $\mathrm{Rb} / \mathrm{Sr}$ deformation ages and suggest that cooling below $\mathrm{c} .350^{\circ} \mathrm{C}$ occurred after juxtaposition of the units by SE-directed extensional deformation.

Our data indicate a complex kinematic history involving both crustal shortening and extension within the internal zones of the Alpine orogen. To constrain the palaeogeographic and geodynamic evolution of the Alps requires that these data be integrated with data from the more external zones of the orogen. Complexity such as that described is unlikely to be restricted to the Western Alps and spatially and temporally variable kinematic data are probably the norm in convergent orogens. Recognising such features is fundamental to the correct tectonic interpretation of both modern and ancient orogens. 


\section{Introduction}

A complete understanding of convergent orogenic processes requires the integration of data from both ancient and modern orogens. Modern collisional orogens provide a unique opportunity to study the accretion and collision of converging continental fragments because they often preserve the upper structural levels of the orogen and enable the spatial and temporal distribution of different rock types to be placed into a geodynamic model. In more ancient orogens, the tectonic reconstruction of convergent orogens is more difficult to assess because of erosion. In addition, the temporal resolution of radiometric dating techniques is often insufficient to recognise the small variations in the timing of geological events that are apparent in younger orogens. Conversely, understanding the processes that have taken place at mid- to lower crustal levels in young orogens is difficult because higher grade rocks may still be buried. Although geophysical studies can provide a 'snap shot' of the present crustal structure, such information does not easily allow the kinematic and temporal details of orogen evolution to be inferred. In this paper, we address this problem by integrating kinematic and geochronological data from the highest-grade units of a young orogen, the Western Alps. Our data document a spatial and temporal kinematic evolution that indicates considerable complexity associated with a 'young' convergent orogen.

The European Western Alps is a well understood orogenic belt that developed through plate divergence and subsequent convergence during the Mesozoic and Tertiary. Research spanning more then 150 years has provided a wealth of information that has enabled the geometries of different tectonostratigraphic units to be constrained at the Earth's surface and inferred at depth (see Pfiffner et al, 1997 and Stampfli, 2001 for recent reviews). Recent geophysical studies have provided further evidence of the deep structure of the Alps (Schmid et al., 1996; Pfiffner et al., 1997; Schmid and Kissling, 2000). As a result, a geodynamic picture of Alpine evolution from post-Variscan rifting and ocean formation to the subsequent plate convergence, oceanic subduction and collision is well documented.

Despite the fact that the geometries of tectonostratigraphic units are well known and can be interpreted within a regional-scale geodynamic framework, the details of Alpine structural evolution, particularly kinematic and timing information in the internal parts of the orogen, are still poorly known. As a consequence, geodynamic models for Alpine evolution are incomplete. Kinematic data from the Western Alps have been interpreted within a convergent 
framework and have been assigned to deformation associated with the thrusting of Austroalpine and Piemonte oceanic units to the NW above the European foreland, or to younger backthrusting (Trumpy, 1980; Milnes et al., 1981; Baird and Dewey, 1986; Lacassin, 1987). However, the internal zones of the Alps record a complex structural evolution in which the kinematics of the deformation vary both spatially and temporally. Recent detailed studies in the internal zones have illustrated that many of the preserved structural features may not be related to NW-directed thrusting but developed during SE-directed extension (Wust and Silverberg, 1989; Wheeler and Butler, 1993) that is linked to the exhumation of eclogite facies units formed by subduction (Ballèvre and Merle, 1993; Reddy et al., 1999b). A regional comparison of the magnitude and timing of this extensional history with convergence and tectonic shortening in the more external parts of the Alps indicates that simultaneous thrusting and extension may be of similar magnitudes (Wheeler et al., 2001). Previous studies have targeted small areas within the orogen for kinematic and geochronological studies and consequently it has been difficult to link these areas to develop a regional kinematic picture through time. However, regional scale information is essential if accretionary and collisional processes in the Alps and other convergent orogens are to be understood in an evolving geodynamic framework.

In this paper we present structural and geochronological information from the internal zones of the Alps exposed in NW Italy. The data we present spans the Penninic, Piemonte and Austroalpine units of the internal zones (Fig. 1); rocks that were juxtaposed and exhumed during subduction and subsequent collision (Platt, 1986; Reddy et al., 1999b; Ring et al., 1999). We concentrate on presenting kinematic information, which we compliment with RbSr analyses from white micas, associated with particular fabrics. In many cases these data can be interpreted in terms of deformation ages and reflect the timing of fabric formation. We also present ${ }^{40} \mathrm{Ar} /{ }^{39} \mathrm{Ar}$ analyses to document the cooling history of the region. The area we have studied is the eastern Val d'Aosta region of northwest Italy, specifically the Sesia, Gressoney, Ayas and Tournanche valleys. We have also undertaken reconnaissance studies to the NW in Switzerland, to place our work in a regional framework. The valleys we have studied provide excellent outcrop through the major units of the Alpine metamorphic zones and have been mapped in detail by the authors. 


\section{Geology of the Western Alpine Internal Zones}

The closure of Neo-Tethys by SE-directed subduction, the accretion of crustal fragments during this convergence and complex interleaving of different tectonostratigraphic units by regional overthrusting and extension has resulted in the formation of the Alpine Orogen (Platt, 1986; Coward and Dietrich, 1989; Schmid et al., 1996; Pfiffner et al., 1997; Schmid and Kissling, 2000; Stampfli, 2001). In the metamorphic areas of the Western Alps, commonly referred to as "the Internal Zones", components of the European (Briançonnais) microcontinent (Penninic Domain), the Adriatic microcontinent (Austroalpine Domain) and the interjacent oceanic plate (Piemonte Unit) are exposed (Fig. 1). Penninic and Austroalpine basement rocks contain evidence of pre-Alpine metamorphism. However, all three major internal zone units have locally developed eclogitic rocks of Alpine age that developed during subduction (Ernst and Dal Piaz, 1978). The units also contain areas that show no evidence of having reached eclogite facies grades, though they record greenschist facies metamorphism.

The Penninic basement is the structurally lowest unit within the internal zones. It comprises the Monte Rosa, Gran Paradiso and Dora Maira massifs, and, in the west, a series of basement nappes which include the Siviez - Mischabel nappe. This basement material is considered to be part of the subducted Briançonnais microcontinent; the rifted continental margin of the European basement (e.g. Stampfli et al, 2001). The southern most outcrops of the Monte Rosa lies within the studied area and comprise garnet mica schists, metagranites and metabasites. Locally preserved omphacite + garnet + glaucophane + zoisite + white mica within metabasites indicate Alpine eclogite facies metamorphism affected this area of Monte Rosa basement (Bearth, 1952; Dal Piaz and Lombardo, 1986).

The structurally highest tectonic units in the Western Alps belong to the Adriatic microcontinent and are referred to as Austroalpine units. Austroalpine basement is further subdivided by geographic location and metamorphic grade. The Sesia Zone represents part of the pre-Alpine Austroalpine basement thrust northwestwards over the Penninic basement and Piemonte oceanic material (Compagnoni et al., 1977). Three main lithotectonic units have been recognised in the Sesia Zone (Compagnoni et al., 1977).

The Eclogite Micaschist Complex is a several kilometre thick unit comprising pre-Alpine high-grade paragneiss with marbles, amphibolites and granulites intruded by Variscan gabbros and granites and metamorphosed at eclogite facies (Vuichard and Ballevre, 1988; 
Pognante, 1989). The eclogite facies assemblages $\left(\mathrm{T} \approx 500-600^{\circ} \mathrm{C}, \mathrm{P}>13 \mathrm{kbar}\right)$ are locally overprinted by a later, greenschist facies metamorphism (Compagnoni et al., 1977).

The Gneiss Minuti Complex contains fine-grained quartz - feldspar schists, with augen orthogneiss, mica schists and metagabbros. These represent pre-Alpine lithologies overprinted by Alpine greenschist facies metamorphism and deformation. The contact of the Gneiss Minuti Complex and underlying Piemonte oceanic unit is a high strain zone accommodating top-to-SE extension after earlier thrusting (Wheeler and Butler, 1993; Reddy et al., 1999b).

The Seconda Zona Diorito Kinzigitica (IIDK) forms the structurally highest unit in the Sesia Zone and comprises pre-Alpine amphibolite facies rocks similar to those found in the Ivrea Zone (Compagnoni et al., 1977). This pre-Alpine metamorphism is also overprinted by a localised low-greenschist facies metamorphism, evident within shear zones close to its margins (Lardeaux et al., 1982; Ridley, 1989), which is of Alpine age (Reddy et al., 1996; Pickles et al., 1997).

Further west, Austroalpine basement forms the Dent Blanche Klippe (Fig. 1). Dent Blanche is subdivided into the high strain Arolla Schist, which preserves Alpine greenschist facies metamorphism and are thought to correlate with the Gneiss Minuti Complex, and the Valpelline Series, the lateral equivalent of the IIDK (Ballèvre et al., 1986).

The Piemonte oceanic unit lying between the Penninic and Austroalpine domains comprises the Jurassic oceanic crust that separated the two continental fragments prior to collision. The unit is sub-divided into two zones based on metamorphic grade. The structurally higher Combin Zone, the lateral equivalent of the Tsaté Nappe in Switzerland, was metamorphosed at greenschist facies during the Alpine orogeny. This unit lies structurally above the eclogite facies Zermatt-Saas Zone.

The Combin Zone is lithologically complex and comprises a range of different rock types (Dal Piaz, 1965; Caby, 1981), which can be subdivided into a number of different units (Ballèvre and Merle, 1993; Escher and Beaumont, 1997). In Italy, the Combin Zone is dominated by carbonate bearing rocks (calcschists) and metabasites that are interbanded at the centimetre to tens of metre scale. Serpentinites and serpentinite breccias are also common and metagabbros are preserved. This sequence of rock types represents a complicated 
amalgamation of oceanic igneous and sedimentary rocks (Dal Piaz, 1965; Bearth, 1967) that were juxtaposed within an accretionary complex on the southern margin of the Piemonte Ocean (Marthaler and Stampfli, 1989). These oceanic rocks lie structurally above a sequence of quartzites, dolomites and marbles, called the Cime Bianchi unit, which are interpreted as being deposited on continental crust and are of probable Briançonnais origin (Escher and Beaumont, 1997).

The metabasites of the Combin Zone have the greenschist facies mineral assemblage actinolite + albite + chlorite + epidote. Calcschists with calcite + quartz + white mica \pm chlorite \pm zoisite \pm albite \pm titanite \pm tremolite / actinolite assemblages are interleaved with metabasites. However, this greenschist assemblage overprints an earlier, poorly preserved, blueschist facies metamorphism (Gosso et al., 1979; Caby, 1981; Ayrton et al., 1982; Sperlich, 1988). Recent estimates of greenschist facies $P$ - $T$ conditions within the Italian Combin Zone is derived from a combination of data from both the metabasites and the calcschists and indicates P-T conditions of c. 9 kbar and 300-450 ${ }^{\circ} \mathrm{C}$ (Reddy et al., 1999b).

In the studied area, the Zermatt Saas Zone comprises metabasic, metagabbroic and serpentinitic rocks, though in the west of the studied area, sedimentary sequences are also recognisable (Dal Piaz and Ernst, 1978; Bearth and Schwander, 1981). Mineral assemblages within the metabasites contain omphacite + garnet + paragonite + phengite + rutile + glaucophane + zoisite + titanite + hornblende $/$ actinolite \pm albite. This disequilibrium suite of minerals reflects the progressive and often complete greenschist retrogression of the eclogite assemblage during exhumation. Petrological studies from well-preserved eclogites in the Zermatt Saas Zone indicate metamorphic conditions of $550-600^{\circ} \mathrm{C}$ and $18-20 \mathrm{kbar}$ for the eclogitic peak (Barnicoat and Fry, 1986). In one locality, there is also evidence for ultra-high pressure metamorphism at $\mathrm{P} \sim 25 \mathrm{kbar}$ (Reinecke, 1991; Reinecke, 1998).

In recent years the timing of eclogite-facies metamorphism in the internal parts of the orogen has been well constrained. U-Pb, Sm-Nd and Lu-Hf data yield ages for eclogite facies metamorphism of c. 65 - 35 Ma. These data indicate that the Sesia Zone eclogites were metamorphosed around 65 Ma ago (Ramsbotham et al., 1994; Rubatto et al., 1999), high pressure metamorphism in the Penninic basement of Dora Maira occurred c. 35 Ma ago (Tilton et al., 1991; Gebauer et al., 1997 ) and, in the intervening Zermatt Saas Zone of the oceanic Piemonte Unit, eclogite facies metamorphism has been inferred at 50-40 Ma 
(Duchêne et al., 1997; Rubatto et al., 1998; Amato et al., 1999). The data therefore indicate Tertiary ages for eclogite facies metamorphism that becomes younger in a NW direction towards the Alpine foreland. The Tertiary age indicate that attempts to link high pressure metamorphism to Cretaceous plate motions (Baird and Dewey, 1986; Escher and Beaumont, 1997) are unrealistic.

The greenschist-facies rocks separating the eclogites are high strain zones and kinematic information combined with regional geometry has shown that some of these zones reflect topto-SE extensional structures (Wheeler and Butler, 1993), associated with eclogite exhumation (Reddy et al., 1999b), rather than SE-directed backthrusts. Locally top-to-NW shear is older than top-to-SE shear (Ring, 1995). The observation of extensional kinematics within a convergent orogen provides an excellent opportunity to investigate the details of eclogite exhumation processes and constrain the complex nature of the spatial and temporal variations in deformation associated with exhumation during plate convergence.

\section{Analytical Procedure}

\section{Structural Analysis}

The Austroalpine, Combin and Zermatt-Saas zones and Monte Rosa Penninic basement have been mapped at 1:10,000 from northern Val Sesia westwards to northern Val Tournanche. Both geometric and kinematic structural data were collected and structural data were analysed stereographically to look at spatial or lithological control on structural geometry. In our previous detailed study of the Val Gressoney we presented a detailed structural history of the Piemonte Unit and surrounding rocks (Reddy et al., 1999b). Our structural analysis of the adjacent valleys indicates a similar structural history to the Val Gressoney. We therefore avoid a detailed repetition of this deformation history (referring the reader to Reddy et al 1999b and references therein) and instead concentrate on the complexities of the kinematic framework associated with foliation and lineation development within regionally exposed ductile shear zones. Although our study has concentrated along a traverse from Val Sesia to Val Tournanche, kinematic data has also been collected from the contiguous units to the west of Dent Blanche in Switzerland. 


\section{$\mathrm{Rb} / \mathrm{Sr}$ Data}

$\mathrm{The} \mathrm{Rb} / \mathrm{Sr}$ data presented here is a compilation of new data and data that has been published by Reddy et al (1999b). Samples for Rb/Sr dating were collected from well-constrained structures across the area. $\mathrm{Rb} / \mathrm{Sr}$ dating was undertaken at the Radiogenic Isotope Laboratory at the University of Leeds, UK. Sample preparation and analytical procedure has been described in detail elsewhere (Freeman et al., 1997; Freeman et al., 1998; Reddy et al., 1999b).

Most of our data comes from the greenschist facies rocks of the region, which contain sufficient white mica and feldspar/calcite to constrain mineral isochrons. $\mathrm{Rb} / \mathrm{Sr}$ dating has concentrated on rocks that show dynamic recrystallisation at greenschist facies, i.e. the rocks were recrystallised at temperatures below the closure temperature for Sr diffusion in white mica (see Reddy et al (1999b) for details). In such situations ages may yield the time of deformation (Reddy and Potts, 1999). However, for this to be the case a single population of micas must be present. The presence of mixed mica populations will lead to mixed ages that may not correspond to the timing of deformation (Freeman et al., 1998). In the Val Gressoney, duplicate analyses of fabrics were undertaken on some samples and in some cases analyses of the same fabrics but in different samples were undertaken to test for internal consistency and reproducibility.

${ }^{40} \mathrm{Ar} /{ }^{39} \mathrm{Ar}$ Data

${ }^{40} \mathrm{Ar} /{ }^{39} \mathrm{Ar}$ dating was undertaken in two stages. Firstly, initial analyses on mineral separates were taken from the whole region to assess the potential contribution of excess argon and to provide a template of argon age data from which a detailed dating programme could be based. For completeness we present this data here. Subsequent data were collected using high-spatial resolution (both infrared (IR) and ultraviolet (UV)) laserprobe, in situ analysis of polished thick sections and involved the multiple analysis of single grains. Samples for study were chosen because they showed little evidence for weathering and they contained suitable phases for ${ }^{40} \mathrm{Ar} /{ }^{39} \mathrm{Ar}$ dating. Where possible, samples were oriented in the field and oriented thin sections of each sample were used for petrographic purposes. Having the samples oriented enabled the relationship between grains analysed in situ to be related to the regional structural framework. 
Mineral separates were obtained by mineral picking of the coarse fraction of samples reduced in a jaw crusher. The coarse fraction was used in an attempt to avoid analysing grains that had undergone grain size reduction in the separation procedure. Although it is difficult to assess this, grains that were selected for analysis had approximately the same grain size as grains seen in thin section. Mineral separates were cleaned in methanol and de-ionised water in an ultrasonic bath prior to irradiation.

The preparation procedure for in situ analysis of thick, polished sections have been described in detail elsewhere (Reddy et al., 1996; Reddy et al., 1997). Each sample, was studied by standard optical petrographic techniques and was investigated using atomic number contrast imaging. For each sample a compositional 'map' was made and used to identify and record the subsequent location of laser analyses. The sections were cleaned ultrasonically in methanol and de-ionised water, before being wrapped in aluminium foil prior to irradiation.

The data presented here were collected over several years in several different analytical batches. Details of reactor and J values for each batch are included in the supplementary data tables. Hb3gr and MMHb-1 hornblende standards were used to monitor the neutron flux during irradiation. The age of the standards used to calculate the $\mathrm{J}$ value were $1072 \mathrm{Ma}$ for Hb3gr (Roddick, 1983) and 520.4 Ma for MMHb-1 (Samson and Alexander, 1987). No significant neutron flux variation $(<0.5 \%)$ was apparent between any of the samples in individual batches.

After irradiation samples were analysed at the laser ${ }^{40} \mathrm{Ar} /{ }^{39} \mathrm{Ar}$ dating laboratory at the Open University, UK. Mineral separate analyses involved multiple, single-grain fusion experiments using the IR laser. Thick section analyses involved either whole grain analysis or, more commonly, multiple, single-spot analyses. Spots sizes were in the order of 50-100 $\mu \mathrm{m}$ diameter for the IR laser. The UV laser enabled more precise sample selection (due in part to a smaller damage halo and better absorption characteristics) and was achieved by rastering a

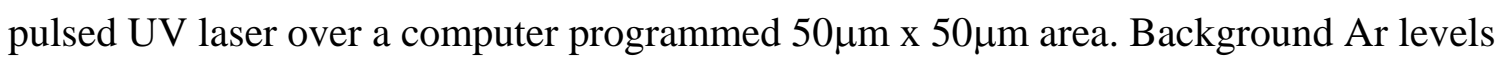
were monitored before and after each sample analysis and the mean of the two blanks was used to correct the sample analyses. Sample analyses were corrected for mass spectrometer discrimination, ${ }^{37} \mathrm{Ar}$ decay and neutron-induced interferences.

The interpretation of ${ }^{40} \mathrm{Ar} /{ }^{39} \mathrm{Ar}$ data can be difficult due to a number of different problems that arise when studying minerals in metamorphic rocks including the presence of excess ${ }^{40} \mathrm{Ar}$ and 
the loss of radiogenic ${ }^{40} \mathrm{Ar}$ if the sample is heated to temperatures approaching its blocking temperature. Excess ${ }^{40} \mathrm{Ar}$ is a non-radiogenic ${ }^{40} \mathrm{Ar}$ component that has not formed from in situ decay of ${ }^{40} \mathrm{~K}$. When present, excess ${ }^{40}$ Ar yields apparent ages that are older than the 'true' age of the sample. To assess the importance of excess ${ }^{40} \mathrm{Ar}$ two approaches can be used. Firstly, on inverse isochron correlation diagrams $\left({ }^{36} \mathrm{Ar} /{ }^{40} \mathrm{Ar} v{ }^{39} \mathrm{Ar} /{ }^{40} \mathrm{Ar}\right.$ ) (Roddick, 1978), excess ${ }^{40} \mathrm{Ar}$ can be recognised if the data fall on a line that does not pass through the atmospheric composition of Ar on the ${ }^{36} \mathrm{Ar} /{ }^{40} \mathrm{Ar}$ axis. However, often the data do not define a line but cluster close to the radiogenic axis and in such situations it is difficult to recognise the presence of an excess component using correlation diagrams. In these situations there are two ways that the age data can be interpreted. The mean age of the data can be calculated or the youngest age can be quoted. In both cases it must be noted that the age may have an excess component and therefore the age is a maximum age for isotopic closure.

The second approach is to undertake multiple, high-spatial resolution, intragrain analyses using a laser to identify age variations that may relate to grain boundaries or microstructures within the grain. Such variations may indicate the presence of excess ${ }^{40} \mathrm{Ar}$ and, in addition, can be used to recognise Ar loss. These approaches have previously been used in this region of the Alps and have yielded important constraints on the timing and duration of deformation and the thermal history of Austroalpine units (Reddy et al., 1996; Pickles et al., 1997). However, this approach is hindered by the time and expense involved with taking large numbers of intra-grain analyses.

In this paper we have undertaken both of the above approaches. We have plotted isotope correlation diagrams for all samples and have quoted the 'best' age for each sample. Where possible we have used the 'corrected' age obtained from the isotope correlation diagram, which accounts for the presence of excess ${ }^{40} \mathrm{Ar}$. However, in many cases we have had to quote the mean age or the youngest age of the data set. Multiple, in situ, laser analyses from individual grains have also been used and these indicate the presence of excess ${ }^{40} \mathrm{Ar}$ in some samples and the loss of radiogenic ${ }^{40} \mathrm{Ar}$ in others. This is documented in the supplementary data e-tables and discussed further in the results section.

\section{Structural and Kinematic Framework}

Geological mapping and observations of mesoscale structures indicate a complex deformation history in the Piemonte and surrounding rocks exposed in the northern ends of the Val Sesia 
to Val Tournanche valleys (Fig. 1). The geometrical distributions of foliations and penetrative lineations are illustrated in Fig. 2. Lineations are either mineral aggregate lineations or represent the alignment of elongate mineral grains on the foliation surface. Kinematic indicators are well developed and this information is summarised in map form (Fig. 3) and in detailed cross sections (Fig 4, a,b,c).

Monte Rosa (Briançonnais Penninic) basement

At the lowest structural levels the Monte Rosa foliations define a range of orientations in Val Gressoney (Fig. 2j) but dip gently south in Val Sesia (Fig. 2n). This reflects folding of the basement rocks at greenschist facies (Gosso et al., 1979; Reddy et al., 1999b) and the different levels of the fold exposed in the different valleys. Lineations are subparallel to the orientation of the fold hinges and kinematic indicators are therefore different on the different limbs of the fold. On the overturned limbs, kinematic indicators are top-to-NW, while top-toSE shear sense indicators are developed on limbs that are not overturned (Fig. 3) (Reddy et al., 1999b). There appears to be a gentle change in the orientation of lineations from NW-SE in the east to W-E in the west (Fig. 2f,j,n).

\section{Zermatt Sass Zone (Lower Piemonte Unit)}

The Zermatt Saas Zone contains two foliations that are recognisable throughout the region. The first is parallel to a compositional banding defined by both primary lithological variations and secondary metamorphic segregation. Areas preserving good eclogite-facies mineral assemblages contain a foliation $\left(\mathrm{S}^{1} \mathrm{zS}\right)$, defined by the alignment of eclogite facies minerals. Lower pressure, greenschist-facies mineral assemblages replace those developed at eclogite facies. Two different types of overprinting can be observed; a heterogeneously developed static overprint preserving relict $S^{1}$ zs fabrics, and a heterogeneously developed, dynamic greenschist foliation $\left(\mathrm{S}^{2} \mathrm{zS}\right)$ that increases in intensity towards the contact with the overlying Combin Zone. Close to the Combin Zone, $\mathrm{S}_{\mathrm{zs}}$ is reoriented towards parallelism with the contact. The different foliations are commonly difficult to discriminate in the field. Foliations in the Zermatt Saas Zone show a change in geometry through the valleys (Fig. 2c,e,i,m). In the west, foliations dip moderately to the NW (Fig. 2c), becoming west dipping in Val d'Ayas (Fig. 2e). In Gressoney, foliation poles define a north-south girdle (fig. 2i), better developed than that in the Monte Rosa data (Fig 2j). This reflects km-scale folds that affect the eclogite facies units in this valley. Mineral lineations in the Zermatt Saas Zone have variable 
orientations throughout the region but generally plunge toward the NW and SE quadrants (Fig. 2c,e,i,m).

Kinematic indicators are poorly developed in the eclogitic Zermatt Saas Zone. However, the $\mathrm{S}^{2} \mathrm{zS}$ foliation has shear bands that record a top-to-SE shear sense in the upper levels of the Zermatt Saas Zone (Fig. 5a). Reorientation of lithological banding and $\mathrm{S}^{1}$ zs in Val Gressoney and Val d'Ayas toward the Combin contact are consistent with this shear sense. Kinematic indicators associated with $S^{1}$ zs occasionally indicate top-to-NW shear. In most cases this is on the overturned limbs of the km-scale greenschist facies folds that fold the Monte Rosa Zermatt Saas Zone contact. However in Val Tournanche, top-to-NW kinematics are observed. The complex $S^{1}$ zs kinematics in Val Tournanche probably reflect complexity associated with the development of post- $S^{1}$ zs, pre- $S^{2}$ zs isoclinal folds (see Reddy et al 1999b).

\section{Combin Zone (Upper Piemonte Unit)}

The Combin Zone is a regionally developed high strain zone, with well-developed greenschist facies foliations and associated lineations. Foliations across the region show a systematic variation dipping south in the east to WNW dipping in the west (Fig. 2b,d,h,i). Lineations are well-developed mineral aggregate lineations (quartz and white mica) or mineral elongation lineations (actinolite) and are NW-SE oriented (Fig. 2b,d,h,i).

Shear sense indicators (shear bands and mica fish) associated with these foliations and lineations are common throughout the Combin Zone (Fig. 5b, c) and indicate considerable kinematic variation. Locally, this kinematic pattern is variable at the $10 \mathrm{~m}$ scale (Fig. 4b). Commonly there is no angular discordance between domains recording different kinematic senses at this scale (Fig. 4b) so that relative ages of fabrics are ambiguous. However, at a larger scale there is a systematic distribution to the preserved kinematic pattern.

In Val Sesia, all kinematic indicators are consistent and record top-to-SE shear (Fig. 3). Similarly, kinematic indicators in the equivalent Tsaté nappe to the west and beneath Dent Blanche show consistent top-to-SE kinematics (fig. 5c). In Val Gressoney, the Combin Zone comprises a number of structural domains. These domains record consistent kinematic sense internally but have slightly different orientations (Fig. 4a). Adjacent domains sometimes record different shear sense and overprinting relationships indicate a complex deformation history involving early top-to-SE shear (Fig. 5b), subsequent top-to-NW shear and localised 
reworking of these foliations by continued top-to-SE shearing (Fig. 4a \& Reddy et al 1999). At a similar scale, variable kinematic senses are seen in Val Tournanche where the structurally higher levels of the Combin Zone record both top-to-NW and top-to-SE senses of shear (Fig. 3; Fig. 4a,b,c). These variations are related to structural level and geographic location. Top-to-SE shear on the eastern side of Val Tournanche contrasts dominantly top-toNW shear where the Combin Zone dips beneath the Dent Blanche Klippe on the west of the valley (Fig. 3, 4c). The Cime Bianchi unit beneath this packet of top-NW Combin shear records top-to-SE kinematics that can be traced across the valley, where it lies beneath top-toSE shear in the overlying oceanic rocks (Fig. 4c).

Austroalpine basement

Although we have undertaken detailed structural and kinematic studies of the contacts between different units in the Sesia Zone (Pickles, 1997), we concentrate here on the lowermost structural levels of the Austroalpine Units; the structurally equivalent Gneiss Minuti Complex and Arolla Schists of the Sesia Zone and Dent Blanche respectively. Both of these units are dominated by fine-grained, well foliated, granitic rocks. In the Gneiss Minuti Complex, foliations dip shallowly to the southeast (Fig. 2g,k), while the Arolla Schist foliations, to the east of Dent Blanche, dip shallowly to the northwest (Fig. 2a). This is due to a late, gentle antiformal doming across the area, which left the Dent Blanche as a synformal Klippe. Mineral lineations associated with these foliations plunge to the SE and NW respectively. The basal part of these units show sheath fold development and high strains.

The kinematics of the Gneiss Minuti Complex and Arolla Schist are different. In Val Gressoney and Val Sesia, the Gneiss Minuti Complex records consistent top-to-SE kinematics. This is the case even where the Gneiss Minuti Complex and Combin contact are folded at the kilometre scale (Reddy et al, 1999b). In contrast, kinematics at the base of the Dent Blanche in Val Tournanche show both top-NW and top-SE shear sense (Fig. 4b). Detailed observations have failed to provide a consistent and systematic set of relative age relationships between these kinematically different fabrics.

Two other areas of exposed, lowermost Austroalpine basement have been investigated. At Bec de Nana top-to-NW shearing contrasts the shear sense in the underlying Combin Zone (Fig. 4c). While in Switzerland on the west side of Dent Blanche, the lowermost section of the 
Arolla Schist record top-SE shearing, similar to that in the immediately underlying Tsaté nappe.

\section{Geochronology}

\section{$\mathrm{Rb} / \mathrm{Sr}$ Data}

A range of ages from 34.8 Ma to 60.4 Ma have been obtained through the region (Table 1). These data are presented in map view (Fig. 6) and in cross sections where more detailed studies have been undertaken (Fig. 4). Most of the ages fall over a restricted range (35-48 $\mathrm{Ma})$. The older ages (44.6 - 47.8 Ma) are restricted to the samples from the contact zone of the Combin and Gneiss Minuti Complex and contain mixed mica populations. The two oldest analyses, yielding 60 Ma ages, are both from single mica populations and are restricted to the lowermost structural levels of the Bec de Nana Klippe (Fig. 4c), where top-to-NW kinematic indicators are well developed.

The white micas obtained from the Zermatt Saas Zone are relatively undeformed and do not appear to have undergone extensive synkinematic recrystallisation at greenschist conditions. It is therefore likely that the ages of 38.2 and 40.5 Ma represent cooling ages.

${ }^{40} \mathrm{Ar} /{ }^{39} \mathrm{Ar}$ data

The results of the Ar analyses are summarised in Tables $2 \& 3$ and Figure 7. Table 2 records the mineral separate data while Table 3 presents the thick section in-situ laserprobe analyses. These tables indicate how the 'best' ages for each sample were calculated. Ages calculated from inverse isochrons use empirically measured ${ }^{40} \mathrm{Ar} /{ }^{36} \mathrm{Ar}$ ratios to remove excess $\mathrm{Ar}$ from the age calculation. The ages shown within the boxes in Tables $2 \& 3$ reflect 'real' ages in which the excess ${ }^{40} \mathrm{Ar}$ component has been removed. Complete data sets showing all of the $\mathrm{Ar}$ data are available as electronic supplementary data (e-Tables 1-5). The ${ }^{40} \mathrm{Ar} /{ }^{39} \mathrm{Ar}$ data record a range of apparent ages in which systematic distributions are difficult to recognise. To facilitate the interpretation of the age date we therefore consider the results from the Penninic Domain, Piemonte Unit and Austroalpine Domain independently before integrating the data. 


\section{Penninic Domain}

The Monte Rosa unit yields ${ }^{40} \mathrm{Ar} /{ }^{39} \mathrm{Ar}$ white mica ages between 35.5 and $80.8 \mathrm{Ma}$ and biotite ages of 41.8-54.3 Ma (Fig. 7; Table 2 \& 3). White mica mineral separate data yield generally old ages and in one case this can be assigned to an excess ${ }^{40} \mathrm{Ar}$ component (see Table 2). In situ analyses of single white mica grains have intragrain age variations from mid-Tertiary to Early Cretaceous (e-Table 1-5). Commonly grains yield older core and younger rim apparent ages. Smaller grains also yield younger ages than coarser grains from the same sample. These data indicate that in some samples there is a component of ${ }^{40} \mathrm{Ar}$ loss and indicate a partial resetting of ${ }^{40} \mathrm{Ar} /{ }^{39} \mathrm{Ar}$ ages. The data do not allow the recognition of an excess ${ }^{40} \mathrm{Ar}$ component in these samples and we cannot therefore access the geological significance of old core ages. However, since Cretaceous ages are older than the eclogite facies metamorphic peak, it is probable that old core ages contain an excess ${ }^{40} \mathrm{Ar}$ component.

The oldest biotite data from the Monte Rosa unit comes from whole grain mineral separate analyses (45.7 - 54.3 Ma). Individual samples yield a range of biotite ages from c.40-80 Ma (e-Table 5). Inverse isochron plots of in situ data (41.8-43.1) indicate the presence of an excess ${ }^{40} \mathrm{Ar}$ component that was not recognisable in the mineral separate data. The youngest ages from both the white mica (37.1 $\pm 7.0 \mathrm{Ma}$ ) and the biotite (41.8 $\pm 1.6 \mathrm{Ma})$ give a maximum age for the timing of the thermal event responsible for (partial) resetting of the $\mathrm{Ar}$ ages. The older age of biotite relative to white mica may indicate a minor excess ${ }^{40} \mathrm{Ar}$ component within the biotite.

To the south of the Aosta Fault, white micas from Gran Paradiso (structurally equivalent to the Monte Rosa) yield white mica ‘best estimate’ ages of 40.4 - 72.0 Ma (Fig . 7). Older ages, up to $160 \mathrm{Ma}$, are contaminated by an excess ${ }^{40} \mathrm{Ar}$ component. The youngest age (40.4 \pm 0.4 Ma) may also contain an excess ${ }^{40} \mathrm{Ar}$ component. However, this age represents a maximum age for isotopic closure. A single biotite sample yields a similar age of 37.1 Ma but again the distribution of ages on an inverse isochron plot does not allow the recognition of a possible excess ${ }^{40} \mathrm{Ar}$ component.

To the north of Monte Rosa, three analyses of samples from the Siviez-Mischabel nappe (Penninic basement) yield old ages of $82-265$ Ma (not shown on Fig. 7). These are likely to be affected by excess ${ }^{40} \operatorname{Ar}$ (Barnicoat et al., 1995) but once again the mineral separate data is insufficient to recognise intragrain variations in age due to excess ${ }^{40} \mathrm{Ar}$. 


\section{Piemonte Unit}

${ }^{40} \mathrm{Ar} /{ }^{39} \mathrm{Ar}$ white mica and amphibole ages obtained from the Zermatt Saas Zone eclogites range from 36 - 67 Ma and 55 - 182 Ma respectively (Fig. 7; Table 2 \& 3). The data show that the latter are affected by excess ${ }^{40} \mathrm{Ar}$ and no geologically significant age can be obtained from the amphibole data. Generally white mica mineral separate data yield older ages than the in situ analyses. In situ data from individual samples commonly define inverse isochrons that indicate an excess component. The recalculated ages, taking account of the excess component, range from 37.5 - 45.0 Ma within valleys north of the Val d'Aosta. A similar age is obtained from the Zermatt Saas Zone north of the Gran Paradiso and south of the Aosta Fault. Younger ages in some samples correspond to smaller grain sizes or the rims of larger grains in which the cores yield older ages. Younger samples therefore appear to reflect a component of ${ }^{40} \mathrm{Ar}$ loss. The few ages derived from inverse isochrons south of Monte Rosa record ages from 39-32 Ma with younger cooling ages in the west (Fig. 7).

The white mica data from the Combin Unit are relatively reproducible for different samples. Ages range from 34.4 - 41.8 Ma and both mineral and in situ analyses yield inverse isochrons indicating no excess ${ }^{40}$ Ar. The absence of an excess Ar in these samples may indicate that weighted mean ages of other Combin samples represent cooling ages. Ages are generally similar throughout the Combin/Tsaté nappe ( 40 Ma). Despite the general similarity in ages across the four valleys, there appears to be a subtle variation in cooling ages from correlation plots within the Piemonte Unit. Ages of 37.5-39.4 Ma in Val Gressoney decrease to 34.4 Ma in Val Tournanche. Combin Zone minimum ages of $~ 40$ Ma in the east decrease to $35 \mathrm{Ma}$ in the west.

\section{Austroalpine Domain}

In the Austroalpine Units overlying the Combin Zone, ${ }^{40} \mathrm{Ar} /{ }^{39} \mathrm{Ar}$ ages are variable (Table 2 \& 3). We have previously reported some of the complexities of Ar data from Austroalpine units (Reddy et al., 1996; Pickles et al., 1997). At its lowermost structural levels, the greenschist facies and high strain Gneiss Minuti Complex record white mica ages from 37.4 - 46.2 Ma (Fig 7; Tables 2 \& 3). The youngest white mica age has a significant error while the possibility of an excess ${ }^{40} \mathrm{Ar}$ component in the older ages cannot be ruled out. A single white mica sample from the laterally equivalent Arolla Schist to the west of Dent Blanche yields a weighted mean age of $48.0 \mathrm{Ma}$. When plotted as an inverse isochron, the data from this 
sample have insufficient spread to assess the possibility of an excess ${ }^{40} \mathrm{Ar}$ component. Biotite ages of 32 Ma are recorded from both analysed samples of the Gneiss Minuti Complex and data plotted as an inverse isochron from one of these (32.1 $\pm 1.1 \mathrm{Ma})$ indicates no excess ${ }^{40} \mathrm{Ar}$. A single sample of amphibole from the greenschist overprinted Pinter metagabbro (Wheeler and Butler, 1993) yields an age of $315 \mathrm{Ma}$, which we attribute to a significant excess component.

The Eclogite Micaschist Complex of the Sesia Zone records a wide range of ages. Individual grains from the same sample yield variable apparent ages are and show the presence of excess ${ }^{40} \mathrm{Ar}$. Apparent ages from these samples are interpreted to be geologically meaningless. Detailed analysis of in situ data shows that samples have heterogeneous ${ }^{40} \mathrm{Ar}$ distributions at an intragrain scale and variable amounts of ${ }^{40}$ Ar loss. Detailed work on one sample (77519) (Reddy et al., 1996) indicates that the distribution of excess Ar reflects both volume diffusion into the edges of the mica grains and a component of diffusion along microstructural features developing within grains during deformation at around $450^{\circ} \mathrm{C}$. The wide range in ages reported here is therefore interpreted to represent variable excess ${ }^{40} \mathrm{Ar}$ linked to the microstructural history of individual grains. A single analysis of a sample from the Emelius Klippe, a lateral equivalent of the Eclogite Micaschist Complex to the south of the Aosta Fault, shows none of the complexity recorded in the Eclogite Micaschist Complex samples and yields reproducible ages of $41.4 \pm 0.5 \mathrm{Ma}$.

A range of biotite ages were obtained from the structurally uppermost Valpelline unit of the Dent Blanche. A similar feature was seen in data from IIDK biotite further east and is related to minor Ar loss from Variscan biotite during Alpine heating at c. $300^{\circ} \mathrm{C}$ (Reddy et al., 1996).

\section{Discussion}

Spatial Complexity in Kinematic Evolution

Structural analysis of a large region of the Western Alpine internal zones indicates the common development of kinematic indicators associated with regionally extensive, highstrain deformation. This greenschist facies deformation is localised in the Combin Zone and extends laterally for almost $50 \mathrm{~km}$ from Val Sesia in the SE to the NW side of Dent Blanche (Fig. 8). Synkinematic greenschist facies metamorphism also occurred in the immediately adjacent rocks of the overlying Austroalpine basement and the structurally lower eclogite 
facies rocks of the Zermatt Saas Zone. Despite simple geometries for foliation and lineation orientations, the kinematic picture is complex with both top-to-NW and top-to SE shear occurring at similar metamorphic grades within the same tectonic unit.

Top-to-SE deformation within the Combin Zone dominates the kinematic picture in most of the study areas (Fig. 8). To the NW of Dent Blanche, within the Cime Bianchi unit, on the eastern side of Val Tournanche and in Val Sesia only top-to-SE kinematics are recorded. Topto-NW kinematics are demonstrated in a single packet of rocks in Val Gressoney and on the western side of Val Tournanche, within or directly beneath the Dent Blanche, but structurally above the Cime Bianchi unit (Fig. 8).

The orientation and kinematic sense of shear zones relative to the present day Earth's surface cannot easily be used to infer a thrusting or extensional geometry at the time of shear zone formation because structures may have undergone subsequent rotation (Wheeler and Butler, 1994; Ring et al., 1999). In the study area, a late, gentle antiformal doming that reoriented earlier structures can be recognised across the area (Fig. 8). Top-to-NW kinematics in Val Gressoney may therefore have a present-day apparent thrust geometry, while a similar shear sense in rocks at the eastern edge of Dent Blanche have an apparent extensional orientation. In addition, the repetition or omission of tectonic units, that can indicate thrust and extensional structures respectively in sedimentary sequences, cannot be easily applied to areas where the original orientation of layering at the time of deformation is unknown (Wheeler and Butler, 1994). Consequently, the best way to infer the regional significance of kinematic information is to examine the regional geometry of structures and establish whether they cut up or down section in the kinematic direction (Wheeler and Butler, 1994; Reddy et al., 1999b).

In Val Gressoney, the Combin Zone is dominated by top-to-SE deformation and dips under Austroalpine rocks and does not re-emerge to the SE. This geometry suggests that the volumetrically most significant top-to-SE deformation was associated with extensional deformation (Fig. 8) (Wheeler and Butler, 1993; Reddy et al., 1999b). The Cime Bianchi unit on the east side of Val Tournanche was affected by the same extensional shear (Fig. 8). On the western side of Val Tournanche, the Cime Bianchi unit has a similar stratigraphy and kinematic sense as that on the other side of the valley. Similarly, the top-to-SE shear at Moiry to the NW of Dent Blanche passes beneath that klippe and re-emerges on the SE side and 
therefore also links to the regional extensional structure mapped from Val Gressoney. Thus, the dominant Combin Zone kinematics, over the region we have studied, are related to regional scale top-to-SE extensional deformation. This interpretation contrasts earlier work which has linked top-to-SE deformation with backthrusting (Trumpy, 1980; Milnes et al., 1981; Baird and Dewey, 1986; Lacassin, 1987).

Although we interpret much of the top-to-SE deformation as extensional, some of the top-toSE deformation may be related to crustal shortening. The Austroalpine units did not originate above the Combin Zone metasediments, so regional extension must post-date large-scale, NW-directed thrusting of the Austroalpine units over the Piemonte Unit and the Penninic Domain. This deformation may still be preserved as domains of top-to-NW fabrics seen throughout the area (Figs. 3,4 \& 8). However, relative age relationships indicate that at least some of the top-to-NW fabrics developed while top-to-SE extension was taking place (Fig. 4a). These fabrics may reflect continuing convergence at the same time as extension (Wheeler et al., 2001) or may reflect thinning of the shear zone by conjugate extensional structures prior to reorientation by later doming.

Geometrically the Combin Zone is a zone of extension that has undergone subsequent folding to produce a regional antiformal dome in the Piemonte Unit and a synformal structure located in the Dent Blanche (Fig. 8). The common limb of this antiform - synform pair passes through the western side of Val Tournanche (Fig. 8). The top-to-NW deformation recorded on western side of Dent Blanche may represent a NW-dipping extensional structure associated with this regional folding. A similar geometry has been described for similar structural levels further south (Philippot, 1990). The test of such a model is that the age of top-to-NW deformation should be younger than the age of gently folded top-to-SE extensional deformation.

It is fundamental to palaeogeographic and geodynamic reconstructions of the Alps that deformation within the Combin Zone / Tsaté nappe is related to regional scale extension. Previous work in the Combin Zone has recognised a tectonic interleaving and complexity that has been interpreted to reflect accretionary prism formation during plate convergence (Marthaler and Stampfli, 1989; Stampfli and Marthaler, 1990). This is a logical model given the oceanic nature of the unit and its current structural position within the Alpine geodynamic framework (Stampfli, 2001). However, a significant component of the Combin Zone 
complexity may reflect the extensional part of the deformation path rather than the accretionary phase. In particular, the tectonic contact at the base of the Cime Bianchi unit always shows SE-directed shears, which cut up tectonostratigraphic section in the transport direction, into the Combin zone calcschists (Fig. 4). This would seem to indicate a backthrust, but only if the Cime Bianchi / Combin Zone package were dipping shallower than the shear at the time of movement. This geometry can be reconciled with the actual extensional nature of the contact if the Cime Bianchi / Combin Zone package was dipping at the time it was emplaced onto the Zermatt Saas Zone (c.f. Wheeler et al 1993, Fig. 10). Consequently the repetition of tectonic units cannot be used in isolation as evidence for their accretionary nature. Clearly our understanding and reconstruction of accretionary orogens cannot be solely based on plate-scale geometries but requires the detailed integration of regional geometry with kinematic information.

\section{Assessment of Alpine Closure Temperatures}

The dynamic recrystallisation of white micas below their closure temperature theoretically gives the timing of recrystallisation and may yield absolute deformation ages (Freeman et al., 1997; Freeman et al., 1998; Reddy and Potts, 1999). A knowledge of the temperature at which deformation takes place and the closure temperature of the minerals recrystallised during the deformation are therefore fundamental to the dating of deformation (Reddy and Potts, 1999). Since the use of closure temperatures was pioneered in the late 1960's (Jäger et al., 1967), the closure temperatures of different minerals and isotope systems have been established by empirical observation and simple diffusion models based on experimentally derived diffusion parameters. Based on these approaches, closure temperatures for muscovite and biotite have been estimated to be $c .500 \pm 50^{\circ} \mathrm{C}$ and $300 \pm 50^{\circ} \mathrm{C}$ respectively for $\mathrm{Sr}$ diffusion (Armstrong et al., 1966; Jäger et al., 1967), and $350 \pm 50^{\circ} \mathrm{C}$ and $300 \pm 50^{\circ} \mathrm{C}$ respectively for Ar diffusion (Armstrong et al., 1966; Pürdy and Jäger, 1976). These closure temperature estimates are still widely used. However, these estimates of closure temperatures have recently been questioned (Villa, 1997) because in many situations the assumption of volume diffusion, the foundation of the closure temperature principal, is not likely to be met. This is particularly the case in deformed or recrystallised minerals and empirical ${ }^{40} \mathrm{Ar} /{ }^{39} \mathrm{Ar}$ studies have illustrated that deformation-induced microstructure plays a significant role in the distribution of Ar low bulk strain minerals (Kramer et al., 2001; Reddy et al., 2001; Mulch et al., 2002). Consequently the 
closure temperatures for "recrystallisation-free" minerals may be significantly higher than most previously published estimates (Villa, 1997).

Temperature estimates for Combin Zone deformation range from $300-450^{\circ} \mathrm{C}$ (Reddy et al., 1999b). This range is below traditional estimates for Sr diffusion in white mica (Jäger et al., 1967), and is also below revised estimates for "recrystallisation-free" white micas of 600$650^{\circ} \mathrm{C}$ (Villa, 1997). Our interpretation that the Rb-Sr white mica ages represent the timing of synkinematic mica growth (see next section) therefore holds independently of which closure temperature is correct. However, Villa's (1997) revised closure temperature for Ar diffusion in white mica of $500^{\circ} \mathrm{C}$ is also above the maximum recrystallisation temperature and ${ }^{40} \mathrm{Ar} /{ }^{39} \mathrm{Ar}$ data should therefore yield identical ages to those obtained by Rb-Sr dating. This is not the case and reliable ${ }^{40} \mathrm{Ar} /{ }^{39} \mathrm{Ar}$ ages (where excess ${ }^{40} \mathrm{Ar}$ can be discounted) are a few million years younger than the Rb-Sr ages. The effective closure temperature for Ar diffusion in white mica must therefore be less than the temperature at which the sample was deformed $\left(300-450^{\circ} \mathrm{C}\right)$. This is not consistent with the revised estimates of Villa (1997) and appears more in accord with lower closure temperature estimates, in particular recent empirical estimates for high grade muscovite (Hames and Bowring, 1994) and slightly higher values derived from low temperature muscovite (Kirschner et al., 1996). Many researchers using closure temperature models to predict temperature - time histories are dealing with naturally deformed metamorphic tectonites and in these cases empirically obtained bulk diffusion data obtained from natural samples may yield better estimates of closure temperature than "recrystallisation-free" estimates. Therefore, although cooling rate and microstructure will complicate matters, we use closure temperatures of $500^{\circ} \mathrm{C}$ for $\mathrm{Rb}-\mathrm{Sr}$ white mica and $350^{\circ}$ and $300^{\circ} \mathrm{C}$ for Ar white mica and biotite respectively. These are consistent with empirically derived diffusion parameters and agree with earlier, less well-constrained values (Armstrong et al., 1966; Jäger et al., 1967; Pürdy and Jäger, 1976).

\section{Temporal Complexity in Kinematic Evolution}

To understand the spatial complexity of deformation outlined earlier we integrate shear sense information with geochronological data on the timing of deformation to develop a temporal framework for the observed kinematic evolution. We have previously used this approach to look in detail at the kinematic evolution of greenschist facies deformation in Val Gressoney (Reddy et al., 1999b). This previous study illustrated a kinematic picture in which top-to-SE extensional deformation was overprinted by top-to-NW deformation followed by strain 
localisation and subsequent top-to-SE overprinting of earlier fabrics at the margins of the Combin Zone (Fig 4a). Analysis of Val Gressoney white micas (Fig. 4a), in which we have found no evidence for multiple mica populations, indicate that ages from different samples within the same part of the shear zone are reproducible, are consistent with relative age relationships obtained from overprinting relationships, and range from 45-36 Ma (Fig. 4a \& 7).

In other areas, we have also shown that $\mathrm{Rb} / \mathrm{Sr}$ dating of white micas recrystallised during greenschist facies deformation at temperatures below their closure temperature have also given regionally consistent ages that have also been interpreted as deformation ages (Freeman et al., 1997; Freeman et al., 1998). We suggest that Rb/Sr white mica ages throughout this study area can be interpreted in a similar manner, that is they date the timing of deformation associated with synkinematic greenschist facies recrystallisation. A cooling age interpretation is inconsistent with the reproducible age variations that are present between adjacent fabric domains in the shear zone.

The oldest $\mathrm{Rb} / \mathrm{Sr}$ ages from the area are two $60 \mathrm{Ma}$ ages from the Austroalpine units of the Pillonet Klippe (Bec de Nana) (Fig. 4c). These data come from single mica populations and rocks metamorphosed at low greenschist grade. The reproducibility of the analyses from two separate samples suggests that the age is geologically meaningful and our interpretation is that the dates record at least part of the top-to-NW deformation path associated with thrusting of the klippe over Piemonte oceanic rocks.

The effects of mixed mica populations on apparent ages are difficult to predict because a) the relative abundance of the populations has not been assessed and b) it is unclear how the mineral separation process may have fractionated these different populations. Directly beneath the Bec de Nana, the Combin Zone yields $\mathrm{Rb} / \mathrm{Sr}$ ages of $c .37 \mathrm{Ma}$ from both single and mixed population samples (Fig. 4c). This suggests that in this case the effects of the mixed population must be minor. The reported 37 Ma ages are similar to ages from the opposite side of the valley that have the same top-to-SE kinematic sense (Fig. 4c) identical to those ages from the lowermost structural levels of the Combin Zone in Val Gressoney (Fig. 4a). Therefore we interpret this age to represent the probable timing of top-to-SE deformation within the Combin Zone at these different localities. 
The age of 48 Ma from the Combin Zone of western Val Tournanche, which records top-toNW kinematics (Fig. 4c), is older than other ages except for the $60 \mathrm{Ma}$ age at the base of the Bec de Nana. This age may reflect the timing of top-to-NW deformation and could therefore indicate that initial top-to-NW thrusting spanned a period of 60-48 Ma. The fact that the Zermatt Saas Zone eclogite facies metamorphism took place in this region between 40-44 Ma (Rubatto et al., 1998; Amato et al., 1999) indicates that subduction of Piemonte oceanic material beneath the Austroalpine hangingwall, must have occurred over this period. Ages of 48 Ma for the timing of NW thrusting in the Sesia Zone (Pickles, 1997) support this possibility. However, the $48 \mathrm{Ma}$ age from Val Tournanche is from a sample with a mixed mica population. A different Rb/Sr mixed mica age (41.5 Ma) from the same structure and similar structural level may indicate that these two ages reflect mixing of older (60Ma?) and younger mica components. A possible young component could be micas recrystallised during late-stage top-to-NW shearing associated with regional folding (Fig. 8). Currently our Rb-Sr data do not allow us to discriminate between these different possiblities.

\section{Post-Kinematic Regional Cooling}

The post-kinematic cooling history of the Western Alpine internal zones can be inferred from our ${ }^{40} \mathrm{Ar} /{ }^{39} \mathrm{Ar}$ data. Data from mineral separates indicate regionally similar age ranges within the same tectonic unit. However, within individual units these ages vary (Fig. 7), often at an intragrain scale (e-Table 1-5). Similar age variations have been documented by ${ }^{40} \mathrm{Ar} /{ }^{39} \mathrm{Ar}$ and K/Ar studies in the Sesia Zone (Ruffet et al., 1995; Reddy et al., 1996; Scaillet, 1996; Pickles, 1997), the Monte Rosa (Chopin and Monie, 1984; Monié, 1985) and the high-pressure rocks of the Piemonte Unit (Bocquet et al., 1974; Hunziker, 1974). The variable ages throughout the region documented by these studies have been interpreted in a number of different ways. Our data indicates that the variability commonly reflects heterogeneous distribution of excess

${ }^{40} \mathrm{Ar}$ and/or the radiogenic ${ }^{40} \mathrm{Ar}$ loss rather than the preservation of different geological events within the samples, (e.g. Monié, 1985).

In some cases, meaningful cooling ages can be obtained from inverse isochron plots. These indicate Tertiary cooling ages for the Penninic and Piemonte Units. However, the presence of excess ${ }^{40} \mathrm{Ar}$ in a large number of the analysed samples calls into question the reliability of $\mathrm{K}$ Ar ages from the internal Alps and therefore the thermal-tectonic models that these data have been used to constrain. In particular our data are clearly in conflict with argon 
geochronological data from the internal Western Alps that record Cretaceous ages and have been used to support Early Cretaceous ages for eclogite facies metamorphism (Hunziker, 1974; Chopin and Monie, 1984; Monié, 1985; Stöckhert et al., 1986; Hunziker et al., 1992). Recent re-evaluation of the timing of eclogite facies metamorphism indicates Tertiary high pressure events (Rubatto et al., 1998; Amato et al., 1999; Rubatto et al., 1999), which are consistent with our ${ }^{40} \mathrm{Ar} /{ }^{39} \mathrm{Ar}$ cooling ages (Fig. 7).

Data interpreted to represent the best estimates of cooling ages from each unit show little inter-unit variation. Monte Rosa ages are similar to those in the Zermatt Saas Zone, the Combin Zone and the basal Austroalpine Units. This suggests that the units were juxtaposed prior to cooling through the Ar closure temperature for white mica and this is consistent with our interpretation that older Rb-Sr ages date the time of deformation and juxtaposition. The subtle variation in correlation ages across the region, with younger ages in the west, suggests rocks cooled earlier in the east. This is not easily reconciled with the extensional model inferred from our kinematic data, which should predict earlier exhumation and cooling of footwall rocks, and therefore older ages, in the west. Earlier we suggested that late, localised top-NW extensional shear beneath the eastern margin of Dent Blanche may be related to synchronous, regional scale open folding (Fig. 8). In such a model, the Zermatt Saas and Combin Zone rocks in the core of the antiformal structure may cool slightly later than rocks in the east. Although Rb-Sr data were equivocal, our Ar data may support this model and suggest that regional folding occurred between 36 - 32 Ma ago, similar to cooling ages in the nearby Siviez-Mischabel nappe (Barnicoat et al., 1995).

Implications for Accretion and Exhumation in Convergent Orogens

Our kinematic and geochronological data indicate a complex spatial and temporal deformation history related to both accretion and subsequent extension. Shear sense indicators and deformation ages are associated with greenschist facies, synkinematic recrystallisation during heterogeneous deformation in the Combin Zone and immediately surrounding rocks. Rarely are primary, accretion-related structures preserved. The relative absence of old, top-toNW fabrics, related to formation of the Combin accretionary complex and thrusting of the Austroalpine Units over the Piemonte Unit, indicates extensive reworking of tectonostratigraphic units after the accretionary phase of tectonism. This is surprising given the ongoing convergence that can be inferred from both the NW migration of the Alpine 
foreland basin in the Tertiary (Sinclair, 1997; Wheeler et al., 2001) and from the timing of thrusting in the Penninic nappes to the west of Dent Blanche (Markley et al., 1998). It indicates that in isolation, kinematic information may be difficult to reconcile with plate-scale displacements.

Greenschist facies strain is dominated by the development of a post-accretionary extensional structure - the Gressoney Shear Zone (Reddy et al., 1999b), which we now suggest extends from Val Sesia to the west of Dent Blanche. This large extent is compatible with the large displacement (>50 km) it must have accommodated (Wheeler et al., 2001). Data presented here support the model of Reddy et al (1999b) that extensional deformation occurred simultaneously with cooling and decompression of eclogite-facies oceanic rocks in the footwall. In addition to SE-directed extension, top-to-NW deformation is present in certain thin panels of rock throughout the greenschist facies shear zone. In places this deformation occurred at broadly the same time, or is bracketed by, top-to-SE extension. Top-to-NW shearing, spatially and temporally linked to the extension process, may be related to continued, possibly episodic, shortening of the Combin Zone accretionary complex or may be reoriented extensional structures associated with tectonic thinning of the shear zone.

The timing of extensional deformation is constrained to between 36-45 Ma. In the Helvetic margin to the west, deformation at 40-45 is taken as the time of initiation of continental collision in the Alps (Platt, 1986; Ring et al., 1999). Much of the extension therefore occurred during the collisional phase of Alpine tectonism. However, eclogite facies metamorphism in the Penninic basement at c.35 Ma (Tilton et al., 1991; Gebauer et al., 1997 ) indicates that extension was taking place while crustal material on the Briançonnais continental margin was being subducted. The overlap in the timing of continent-continent collision and subduction may reflect along strike irregularities in palaeogeography. However, it may also indicate that extensional deformation in the Combin Zone took place during the transition from an accretionary-subduction system to continent-continent collisional.

The geodynamic evolution of the Western Alps has received much recent attention due to extensive geophysical studies (Schmid et al., 1996; Pfiffner et al., 1997; Schmid and Kissling, 2000). However, the complex spatial and temporal kinematic framework we have demonstrated is not apparent in geophysical imaging. As a consequence, the significance of crustal extension in Alpine evolution tends to be neglected. This significant deformation 
episode must be integrated into geodynamic models for Alpine evolution. We have demonstrated that in greenschist facies rocks of the internal zones top-to-SE extensional shearing dominates the preserved structural history. These observations are at odds with wellestablished models for Alpine convergence in which crustal blocks are progressively accreted onto the northern margin of the Adriatic microcontinent. The contrasting plate-scale and unitscale kinematic observations indicate that in more ancient orogens where the geodynamic evolution is less well understood, regionally developed kinematic indicators may represent only a small part of the complete deformation history and may therefore be difficult to interpret within a plate-tectonic framework.

\section{Conclusions}

Within the internal zones of the Western Alps, a regionally developed shear zone has a geometry and kinematic framework that are inconsistent with formation during imbrication of crustal units within an accretionary complex. The dominant kinematic indicators over a NWSE distance of c. $50 \mathrm{~km}$ show that the deformation represents large-scale, SE-directed extensional reactivation of convergent structures. This extension was responsible for the exhumation of eclogite-facies rocks in the footwall of the shear zone. Absolute deformation ages, derived from $\mathrm{Rb} / \mathrm{Sr}$ dating of synkinematic recrystallised white micas, indicate that extensional deformation was heterogeneous and migrated through the shear zone during its 45-36 Ma evolution. Local top-to-NW kinematics within the shear zone were associated with different stages of the deformation history and record pre-extensional thrusting, synextensional convergence and possibly top-to-NW extension associated with thinning of the shear zone and/or late-stage regional scale folding. ${ }^{40} \mathrm{Ar} /{ }^{39} \mathrm{Ar}$ ages indicate cooling after juxtaposition of the different units and this is consistent with the interpretation that Rb-Sr ages date the timing of deformation. Ar data also provide evidence for later localised reworking of the shear zone. This spatial and temporal kinematic complexity means that previous models of Alpine geodynamics must be reassessed.

\section{Acknowledgements}

The data presented in this paper were obtained through Natural Environment Research Council grant GR3/8606. SMR would like to thank IGCP 453, UNESCO and the Tectonics Special Research Centre (TSRC) for financial assistance to attend IGCP 453 in Switzerland. 
This paper forms TSRC publication No. 204 and contributes to the TSRC's Program 4:

“Tectonic Processes”.

\section{References}

Amato, J.M., Johnson, C.M., Baumgartner, L.P. and Beard, B.L., 1999. Rapid exhumation of the Zermatt-Saas ophiolite deduced from high-precision Sm-Nd and Rb-Sr geochronology. Earth Planet. Sci. Letts. 171, 425-438.

Armstrong, R.L., Jäger, E. and Eberhardt, P., 1966. A comparison of K-Ar and Rb-Sr ages on Alpine biotites. Earth Planet. Sci. Letts. 1, 13-19.

Ayrton, S., Bugnon, C., Haarpaintner, T., Weidmann, M. and Frank, E., 1982. Géologie du front de la nappe de Dent Blanche dans la région des Mont-Dolins, Valais. Eclogae geol. Helv. 75, 269-286.

Baird, A.W. and Dewey, J.F., 1986. Structural evolution in thrust belts and relative plate motion - the upper Pennine Piemont zone of the internal Alps, southwest Switzerland and northwest Italy. Tectonics 5, 375-387.

Ballèvre, M., Keinast, J.R. and Vuichard, J.P., 1986. La "nappe de la Dent Blanche" (Alpes Occidentales): Deux unités Austroalpines indépendantes. Eclogae geol. Helv. 79, 57-74.

Ballèvre, M. and Merle, O., 1993. The Combin Fault: compressional reactivation of a Late Cretaceous-Early Tertiary detachmnet fault in the Western Alps. Schweiz. Min. Petrogr. Mitt. 73, 205-227.

Barnicoat, A.C. and Fry, N., 1986. High-pressure metamorphism of the Zermatt-Saas ophiolite zone, Switzerland. J. Geol. Soc. Lond. 143, 607-618.

Barnicoat, A.C., Rex, D.C., Guise, P.G. and Cliff, R.A., 1995. The timing of and nature of greenschsit facies deformation and metamorphism in the Upper Pennine nappes. Tectonics 14, 279-293.

Bearth, P., 1952. Geologie and petrologie des Monte Rosa, Beiträge zur Geologischen Karte der Schweiz.

Bearth, P., 1967. Die Ophiolite der Zone von Zermatt-Saas. Beitr. geol. Karte Schweiz 132.

Bearth, P. and Schwander, H., 1981. The post-triassic sediments of the ophiolite zone Zermatt-Sas Fee and the associated manganese mineralizations. Eclogae geol. Helv. 74, 189-205.

Bocquet, J., Delaloye, M., Hunziker, J.C. and Krummanacher, D., 1974. K-Ar and Rb-Sr dating of blue amphiboles, micas and associated minerals from the Western Alps. Contrib. Mineral. Petrol. 47, 7-26.

Caby, R., 1981. Le Mésozoique de la zone du Combin en Val d'Aoste (Alpes graies): Imbrications tectonique entre séries issues des domaines pennique, austroalpin et océanique. Géologie Alpine 57, 5-13.

Chopin, C. and Monie, P., 1984. A unique magnesiochloritoid - bearing, high-pressure assemblage from the Monte Rosa, Western Alps: petrologic and ${ }^{40} \mathrm{Ar} /{ }^{39} \mathrm{Ar}$ radiometric study. Contrib. Mineral. Petrol. 87, 388-398.

Compagnoni, R., Dal Piaz, G.V., Hunziker, J.C., Gosso, G., Lombardo, B. and Williams, P.F., 1977. The SesiaLanzo Zone, a slice of continental crust with Alpine high pressure - low temperature assemblages in the western Italian Alps. Rend. Soc. It. Mineral. Petrol. 33, 281-334.

Coward, M. and Dietrich, D., 1989. Alpine tectonics - an overview. In: M. Coward, D. Dietrich and R.G. Park (Editors), Alpine Tectonics. Geol. Soc. Spec. Publ., 45, pp. 1-29.

Dal Piaz, G.V., 1965. La formation mesozoica dei calcescisti con pietre verdi fra la Valsesia e la Valtournanche ed i suoi rapporti strutturalli con il recoprimento Monte Rosa e con la Zona Sesia-Lanzo. Boll. Soc. Geol. It. 84, 67-104.

Dal Piaz, G.V. and Ernst, W.G., 1978. Areal geology and petrology of eclogites and associated metabasites of the Piemonte Ophiolite Nappe, Breuil-St. Jacques, Italian Western Alps. Tectonophysics 51, 99-126.

Dal Piaz, G.V. and Lombardo, B., 1986. Early Alpine eclogite metamorphism in the Penninic Monte Rosa Gran Paradiso basement nappes of the north-western Alps. Geol. Soc. Am. Mem. 164, 249-265.

Duchêne, S., Blichert-Toft, J., Luais, B., Télouk, P., Lardeaux, J.-M. and Albarède, F., 1997. The Lu-Hf dating of garnets and the ages of Alpine high-pressure metamorphism. Nature 387, 586-589.

Ernst, W.G. and Dal Piaz, G.V., 1978. Mineral parageneses of eclogitic rocks and related mafic schists in the Piemonte ophiolite nappe, Breuil St. Jacques, Italian Western Alps. American Mineralogist 63, 621640.

Escher, A. and Beaumont, C., 1997. Formation, burial and exhumation of basement nappes at crustal scale: a geometric model based on the Western Swiss-Italian Alps. J. Struct. Geol. 19, 955-974.

Freeman, S.R., Inger, S., Butler, R.W.H. and Cliff, R.A., 1997. Dating deformation using Rb-Sr in white mica: Greenschist facies deformation ages from the Entrelor shear zone, Italian Alps. Tectonics 16, 57-76. 
Freeman, S.R., Butler, R.W.H., Cliff, R.A. and Rex, D.C., 1998. Direct dating of mylonite evolution; a multidisciplinary geochronological study from the Moine thrust zone, NW Scotland. J. Geol. Soc. Lond. 155, 745-758.

Gebauer, D., Schertl, H.-P., Brix, M. and Schreyer, W., 1997. 35 Ma old ultrahigh-pressure metamorphism and evidence for very rapid exhumation in the Dora Maira Massif, Western Alps. Lithos 41, 5-24.

Gosso, G., Dal Piaz, G.V., Piovano, V. and Polino, R., 1979. High pressure emplacement of early-Alpine nappes, postnappe deformations and structural levels (internal northwestern Alps). Mem. Inst. Geol. Min. Univ. Padova 32, 1-15.

Hames, W.E. and Bowring, S.A., 1994. An empirical evaluation of the argon diffusion geometry in muscovite. Earth Planet. Sci. Letts. 124, 161-167.

Hunziker, J.C., 1974. Rb-Sr and K-Ar sge determination and the Alpine tectonic history of the western Alps. Mem. Inst. Geol. Min. Univ. Padova 31, 3-54.

Hunziker, J.C., Desmons, J. and Hurford, A.J., 1992. Thirty-two years of geochronological work in the Central and Western Alps: a review on seven maps. Mémoire de Géologie (Lausanne) 13, 59pp.

Jäger, E., Niggli, E. and Wenk, E., 1967. Rb-Sr Alterbestimmungen an Glimmern der Zentral alpen. Beitr. Geol. Karte Schweiz., 134, 67 pp.

Kirschner, D.L., Cosca, M.A., Masson, H. and Hunziker, J.C., 1996. Staircase ${ }^{40} \mathrm{Ar} /{ }^{39} \mathrm{Ar}$ spectra of fine-grained white mica - Timing and duration of deformation and empirical constraints on argon diffusion. Geology 24, 747-750.

Kramer, N., Cosca, M.A. and Hunziker, J.C., 2001. Heterogeneous ${ }^{40} \mathrm{Ar} *$ distributions in naturally deformed muscovite: in-situ UV-laser ablation evidence for microstructurally controlled intragrain diffusion. Earth Planet. Sci. Letts. 192, 377-388.

Lacassin, R., 1987. Kinematics of ductile shearing from outcrop to crustal scale in the Monte Rosa nappe, Western Alps. Tectonics 6, 69-88.

Lardeaux, J.-M., Gosso, G., Kienast, J.-R. and Lombardo, B., 1982. Relations entre le metamorphisme et la déformation dans la zone Sesia-Lanzo (Alpes Occidentales) et le problème de l'éclogitisation de la croûte continentale. Bull. Soc. Géol. France 24, 793-800.

Markley, M.J., Teyssier, C., Cosca, M.A., Caby, R., Hunziker, J.C. and Sartori, M., 1998. Alpine deformation and ${ }^{40} \mathrm{Ar} /{ }^{39} \mathrm{Ar}$ geochronology of synkinematic white mica in the Siviez-Mischabel Nappe, western Pennine Alps, Switzerland. Tectonics 17, 407-425.

Marthaler, M. and Stampfli, G.M., 1989. Les schistes lustrés à ophiolites de la nappe du Tzaté: un ancien prisme d'accretion issu de la marge active appulienne. Schweiz. Mineral. Petrogr. Mitt. 69, 211-216.

Milnes, A.G., Greller, M. and Müller, R., 1981. Sequence and style of major post-nappe structures, SimplonPennine Alps. J. Struct. Geol. 3, 411-420.

Monié, P., 1985. La méthode ${ }^{39} \mathrm{Ar}-{ }^{40} \mathrm{Ar}$ appliquée au metamorphisme alpin dans le massif du Mont-Rose (alpes Occidentales). Chronologie détailee depuis 110Ma. Eclogae geol. Helv. 78, 487-516.

Mulch, A., Cosca, M.A. and Handy, M.R., 2002. In-situ UV-laser geochronology of a micaceous mylonite: an example of defect-enhanced argon loss. Contrib. Mineral. Petrol. 142, 738-752.

Pfiffner, O.A., Lehner, P., Heitzmann, P., Mueller, S. and Steck, A., 1997. Deep Structure of the Swiss Alps: Results of NRP 20. Berkhäuser Verlag, Basel, 380 pp.

Philippot, P., 1990. Opposite vergence of nappes and crustal extension in the French-Italian western Alps. Tectonics 9, 1143-1164.

Pickles, C.S., 1997. Constraints on the Structural and Metamorphic Evolution of Tectonic Contacts using ${ }^{40} \mathrm{Ar} /{ }^{39} \mathrm{Ar}$ Laserprobe Techniques: The Sesia Zone, Italian Western Alps. Ph.D Thesis, Liverpool University, Liverpool, 160 pp.

Pickles, C.S., Kelley, S.P., Reddy, S.M. and Wheeler, J., 1997. Determinations of high spatial resolution argon isotope variations in metamorphic biotites. Geochim. Cosmochim. Acta 61, 3809-3824.

Platt, J.P., 1986. Dynamics of orogenic wedges and the uplift of high-pressure metamorphic rocks. Geol. Soc. Am. Bull. 97, 1037-1053.

Pognante, U., 1989. Lawsonite, blueschist and eclogite formation in the southern Sesia Zone (western Alps, Italy). Eur. J. Mineral. 1, 89-104.

Pürdy, J.W. and Jäger, E., 1976. K-Ar ages on rock-forming minerals from the central Alps. Mem. Inst. Geol. Min. Univ. Padova 30, 1-32.

Ramsbotham, W., Inger, S., Cliff, B., Rex, D.C. and Barnicoat, A., 1994. Time constraints on the metamorphic and structural evolution of the southern Sesia Zone, Western Italian Alps. Min. Mag. 58A, 758-759.

Reddy, S.M., Kelley, S.P. and Wheeler, J., 1996. A ${ }^{40} \mathrm{Ar} /{ }^{39} \mathrm{Ar}$ laserprobe study of rocks from the Sesia Zone: Excess argon, argon loss and implications for metamorphic and deformation histories. J. metamorphic Geol. 14, 493-508. 
Reddy, S.M., Kelley, S.P. and Magennis, L., 1997. A microstructural and argon laserprobe study of shear zone development on the western margin of the Nanga Parbat Syntaxis, north Pakistan. Contrib. Mineral. Petrol. 128, 16-29.

Reddy, S.M. and Potts, G.J., 1999. Constraining absolute deformation ages: The relationship between deformation mechanisms and isotope systematics. J. Struct. Geol. 21, 1255-1265.

Reddy, S.M., Potts, G.J., Kelley, S.P. and Arnaud, N.O., 1999a. The effects of deformation-induced microstructures on intragrain ${ }^{40} \mathrm{Ar} /{ }^{39} \mathrm{Ar}$ ages in potassium feldspar. Geology 27, 363-366.

Reddy, S.M., Wheeler, J. and Cliff, R.A., 1999b. The geometry and timing of orogenic extension: an example from the Western Italian Alps. J. metamorphic Geol. 17, 573-589.

Reddy, S.M., Potts, G.J. and Kelley, S.P., 2001. ${ }^{40} \mathrm{Ar} /{ }^{39} \mathrm{Ar}$ ages in deformed potassum feldspar: evidence of microstructural control on Ar isotope systematics. Contrib. Mineral. Petrol. 141, 186-200.

Reinecke, T., 1991. Very high-pressure metamorphism and uplift of coesite-bearing metasediments from the Zermatt-Saas Zone, Western Alps. Eur. J. Mineral. 3, 1-17.

Reinecke, T., 1998. Prograde high- to ultra-pressure metamorphism and exhumation of oceanic sediments at Lago di Cignana. Lithos 42, 147-189.

Ridley, J., 1989. Structural and metamorphic history of a segment of the Sesia-Lanzo zone, and its bearing on the kinematics of Alpine deformation in the western Alps. In: M.P. Coward, D. Dietrich and R.G. Park (Editors), Alpine Tectonics, Geol. Soc. Spec. Publ., 45, pp. 189-201.

Ring, U., 1995. Horizontal contraction or horizontal extension: Heterogeneous Late Eocene and Early Oligocene general shearing during blueschist- and greenschist-facies metamorphism at the Pennine-Austroalpine boundary zone in the Western Alps. Geol. Runds. 84, 843-859.

Ring, U., Brandon, M.T., Willett, S.D. and Lister, G.S., 1999. Exhumation processes. In: U. Ring, M.T. Brandon, G.S. Lister and S.D. Willett (Editors), Exhumation Processes: Normal Faulting, Ductile Flow and Erosion. Geological Society Special Publication, pp. 1-27.

Roddick, J.C., 1978. The application of isochron diagrams in ${ }^{40} \mathrm{Ar}^{39} \mathrm{Ar}$ dating : a discussion. Earth Planet. Sci. Letts. 41, 233-244.

Roddick, J.C., 1983. High precision intercalibration of ${ }^{40} \mathrm{Ar} /{ }^{39} \mathrm{Ar}$ standards. Geochim. Cosmochim. Acta 47, 887898.

Rubatto, D., Gebauer, D. and Fanning, M., 1998. Jurassic formation and Eocene subduction of the ZermattSaas-Fee ophiolites: implications for the geodynaic evolution of the Central and Western Alps. Contrib. Mineral. Petrol. 132, 269-287.

Rubatto, D., Gebauer, D. and Compagnoni, R., 1999. Dating of eclogite-facies zircons: the age of Alpine metamorphism in the Sesia-Lanzo zone (Western Alps). Earth Planet. Sci. Letts. 167, 141-158.

Ruffet, G., Feraud, G., Ballevre, M. and Kienast, J.R., 1995. Plateau ages and excess argon in phengites: an 40Ar-39Ar laser probe study of Alpine micas (Sesia Zone, Western Alps, nothern Italy). Chem. Geol. 121, 327-343.

Samson, S.D. and Alexander, E.C., 1987. Calibration of the interlaboratory ${ }^{40} \mathrm{Ar} /{ }^{39} \mathrm{Ar}$ dating standard - MMhb-1. Chem. Geol. 66, 27-34.

Scaillet, S., 1996. Excess ${ }^{40} \mathrm{Ar}$ transport scale and mechanism in high-pressure phengites - a case study from an eclogitized metabasite of the Dora-Maira Nappe, Western Alps. Geochim. Cosmochim. Acta 60, 10751090.

Schmid, S.M., Pfiffner, O.A., Froitzheim, N., Schönborn, G. and Kissling, E., 1996. Geophysical-geological transect and tectonic evolution of the Swiss-Italian Alps. Tectonics 15, 1036-1064.

Schmid, S.M. and Kissling, E., 2000. The arc of the western Alps in the light of geophysical data on dep structure. Tectonics 19, 62-85.

Sinclair, H.D., 1997. Tectonostratigraphic model for underfilled peripheral foreland basins:An Alpine perspective. Geol. Soc. Am. Bull. 109, 324-346.

Sperlich, R., 1988. The transition from crossite to actinolite in metabasites of the Combin unit in Vallee St. Barthélemy (Aosta, Italy). Schweiz. Mineral. Petrogr. Mitt. 68, 215-224.

Stampfli, G.M. and Marthaler, M., 1990. Divergent and convergent margins in the North-Western Alps confrontation to actualistic models. Geodinamica Acta 4, 159-184.

Stampfli, G.M., 2001. Geology of the western Swiss Alps - a guide book. Mém. Géol. (Lausanne) 36, 195pp.

Stöckhert, B., Jäger, E. and Voll, G., 1986. K-Ar age determinations on phengites from the internal part of the Sesia Zone, Western Alps, Italy. Contrib. Mineral. Petrol. 92, 456-470.

Tilton, G.R., Schreyer, W. and Schertl, H.P., 1991. Pb-Sr-Nd isotopic behaviour of deeply subducted crustal rocks from the Dora Maira Massif, W. Alps, Italy - II: What is the age of the ultra high-pressure metamorphism? Contrib. Mineral. Petrol. 108, 22-33.

Trumpy, R., 1980. Geology of Switzerland: A Guide Book. Wepf, Basel.

Villa, I.M., 1997. Isotopic closure. Terra Nova 10, 42-47. 
Vuichard, J.P. and Ballevre, M., 1988. Garnet - chloritoid equilibria in eclogitic pelitic rocks from the Sesia Zone (Western Alps) - their bearing on phase-relations in high-pressure metapelites. J. metamorphic Geol. 6, 135-157.

Wheeler, J. and Butler, R.H.W., 1993. Evidence for extension in the western Alpine orogen - The contact between the oceanic Piemonte and overlying continental Sesia units. Earth Planet. Sci. Letts. 117, 457474.

Wheeler, J. and Butler, R.W.H., 1994. Criteria for identifying structures related to true crustal extension in orogens. J. Struct. Geol. 16, 1023-1027.

Wheeler, J., Reddy, S.M. and Cliff, R.A., 2001. Kinematic linkage between internal zone extension and shortening in the more external units in the NW Alps. J. Geol. Soc. Lond. 158, 439-443.

Wust, G.H. and Silverberg, D.S., 1989. Northern Combin zone complex-Dent Blanche nappe contact: extension within the convergent Alpine Belt. Schweiz. Min. Petrogr. Mitt. 69, 251-259. 


\section{Figures Captions}

Fig. 1. Simplified geological map of the Western Alps. Marked areas indicates the location of structural (Fig. 3) and geochronology figures (Fig. 6, 7).

Fig. 2. Lower hemisphere, equal area stereonets of representative structural data from major units in an west-east traverse (Val Tournanche to Val Sesia). Black symbols represent poles to foliations; white symbols represent mineral lineations.

Fig. 3. Simplified geological map of the internal zones of the Western Alps north of the Aosta fault. Arrow orientation represents the orientation of mineral lineations interpreted to indicate shear sense. The arrowheads indicate the sense of shear, i.e. the relative displacement of the hangingwall. See text for details. Grey lines a, b \& c indicate the locations of the cross sections shown in Fig. 4. EMC = Eclogitic micaschist complex; GMC = Gneiss Minuti Complex; IIDK = Seconda Zona Diorito Kinzigitica; MR = Monte Rosa; AS = Arolla Schist; VP = Valpelline; $\mathrm{PK}=$ Pillonet Klippe.

Fig. 4. Geological cross sections illustrating complex kinematics and Rb-Sr data from three areas. Arrows show relative displacement of hangingwall. Rb-Sr data are documented in terms of single and mixed mica populations (see text for details). Locations of cross sections are shown in Fig. 3. a) Cross section through the Val Gressoney (see Reddy et al. (1999) for details). Domains of consistent kinematics show relative overprinting relationships indicating early top-to-SE followed by top-to-NW deformation. Zones of younger top-SE deformation overprint both of these older domains and indicate strain localisation at the present day contacts between the different units. Rb-Sr data from these different domains record reproducible ages that show a systematic relationship to inferred relative age relationships. b) Complex kinematics at the contact of the Combin Zone and overlying Dent Blanche. Mineral lineations throughout this zone are consistently oriented. c) Kinematic framework through the Dent Blanche, Combin Zone and Zermatt Saas Zone in southern Val Tournanche. Consistent lineation orientations are seen throughout all units. $\mathrm{Rb} / \mathrm{Sr}$ data indicate poorly constrained ages on the west of Val Tournanche but well-constrained, and relative old, ages in the east.

Fig. 5. Kinematc indicators developed in the Piemonte Unit. All photos are oriented NW-SE with SE to the right. a) Greenschist facies shear bands in the Zermatt Saas Zone indicating top-to-SE shear. Shear bands overprint composite $\mathrm{S}_{\mathrm{zs}}{ }^{1}$ and $\mathrm{S}_{\mathrm{zs}}{ }^{2}$ fabrics (Val Gressoney); b) 
Top-to-SE shear bands in Combin calcschists (Val Gressoney); c) Top-to-SE shear bands in calcschists of the Tsaté Nappe (Lac de Moiry, Switzerland).

Fig. 6. Simplified geological map of the internal zones of the Western Alps, north of the Aosta fault, showing the distribution of $\mathrm{Rb} / \mathrm{Sr}$ ages. See text for further discussion. EMC = Eclogitic micaschist complex; GMC = Gneiss Minuti Complex; IIDK = Seconda Zona Diorito Kinzigitica; MR = Monte Rosa; AS = Arolla Schist; VP = Valpelline; PK = Pillonet Klippe.

Fig. 7. Simplified geological map of the internal zones of the Western Alps showing the spatial distribution of ${ }^{40} \mathrm{Ar} /{ }^{39} \mathrm{Ar}$ ages. See text for details. EMC $=$ Eclogitic micaschist complex; GMC = Gneiss Minuti Complex; IIDK = Seconda Zona Diorito Kinzigitica.

Fig. 8. Summary of kinematic information across a schematic cross section through the western Alpine internal zones. Kinematic data from greenschist-facies rocks NW of the Sesia Zone are dominated by top-to-SE extensional deformation. Similar kinematics dominate foliation development in the Combin Zone / Tsaté nappe to the west of Dent Blanche. More complex kinematics are seen in the middle of the cross section. However, integration of these data with absolute dating of the foliations indicates a systematic picture of early top-NW shearing overprinted by top-to-SE extension. The timing of top-to-NW foliations directly beneath Dent Blanche are poorly constrained but on a regional scale appear to be younger than top-to-SE fabrics. Kinematic information from the IIDK are taken from Pickles (1997). EMC $=$ Eclogitic micaschist complex; GMC = Gneiss Minuti Complex; IIDK = Seconda Zona Diorito Kinzigitica; AS = Arolla Schist; VP = Valpelline; SM = Siviez-Mischabel Nappe.

\section{Table Captions}

Table 1. Summary of Rb-Sr white mica ages.

Table 2. Summary of ${ }^{40} \mathrm{Ar} /{ }^{39} \mathrm{Ar}$ mineral separate data. Summary ages are calculated after inspection of data by inverse isochron correlation diagrams (see text for details). Errors are quoted at $1 \sigma$.

Table 3. Summary of ${ }^{40} \mathrm{Ar} /{ }^{39} \mathrm{Ar}$ data collected by in situ laserprobe analysis of thick sections. Summary ages are calculated after inspection of data by inverse isochron correlation diagrams 
and by reference to the intra-grain age distribution of ages that are used to detect Ar loss or the presence of heterogeneous excess ${ }^{40} \mathrm{Ar}$ (see text for details). Errors are quoted at $1 \sigma$.

\section{Supplementary Electronic Data Tables}

e-Tables 1-5. ${ }^{40} \mathrm{Ar} /{ }^{39} \mathrm{Ar}$ data from mineral separate (1) and in situ laserprobe dating of petrographic thick sections (2-5). Reactor and J values for different irradiation batches are given beneath each table. Errors are quoted at $1 \sigma$. 


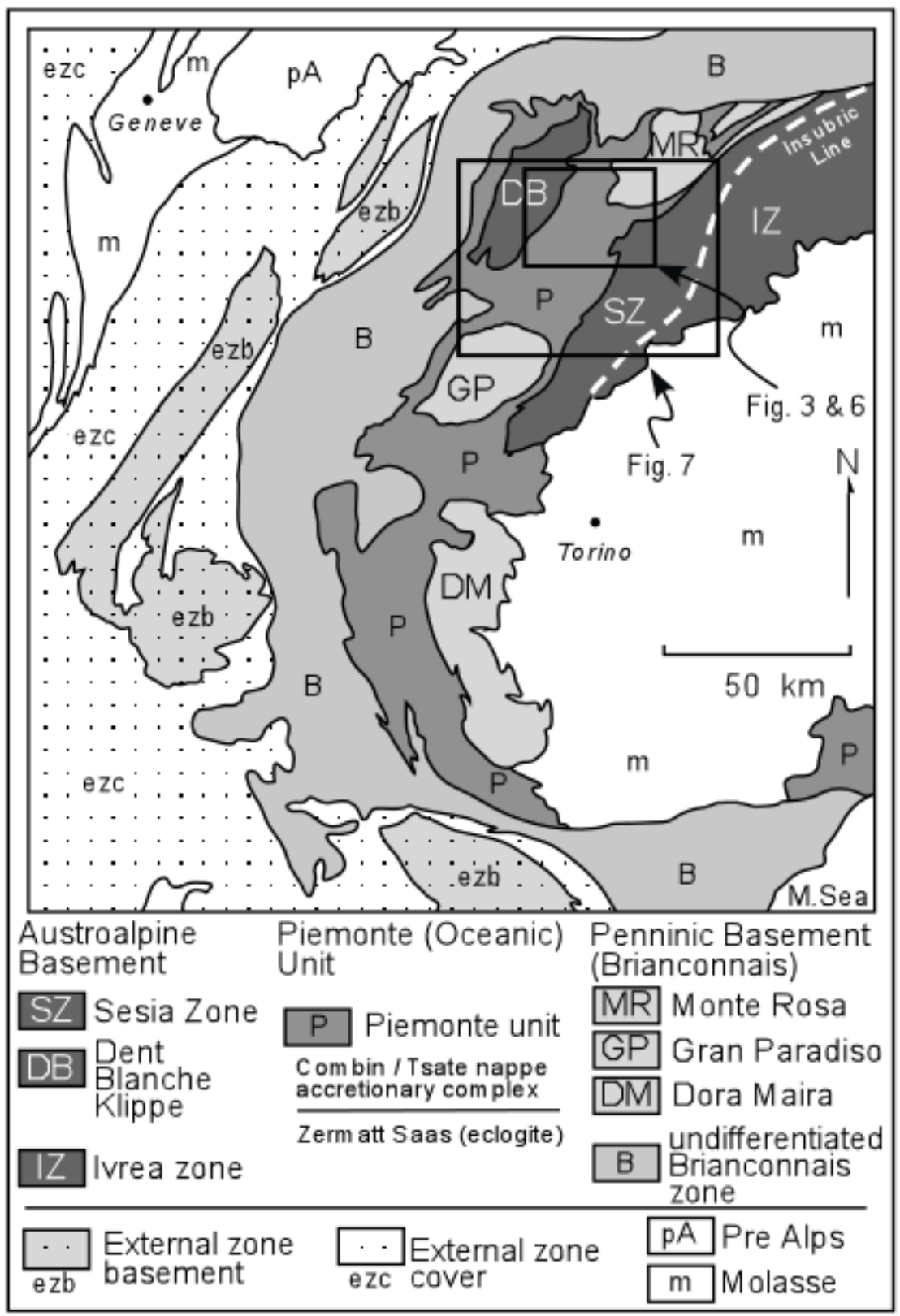

Reddy et al. / Tectonophysics Figure 1 


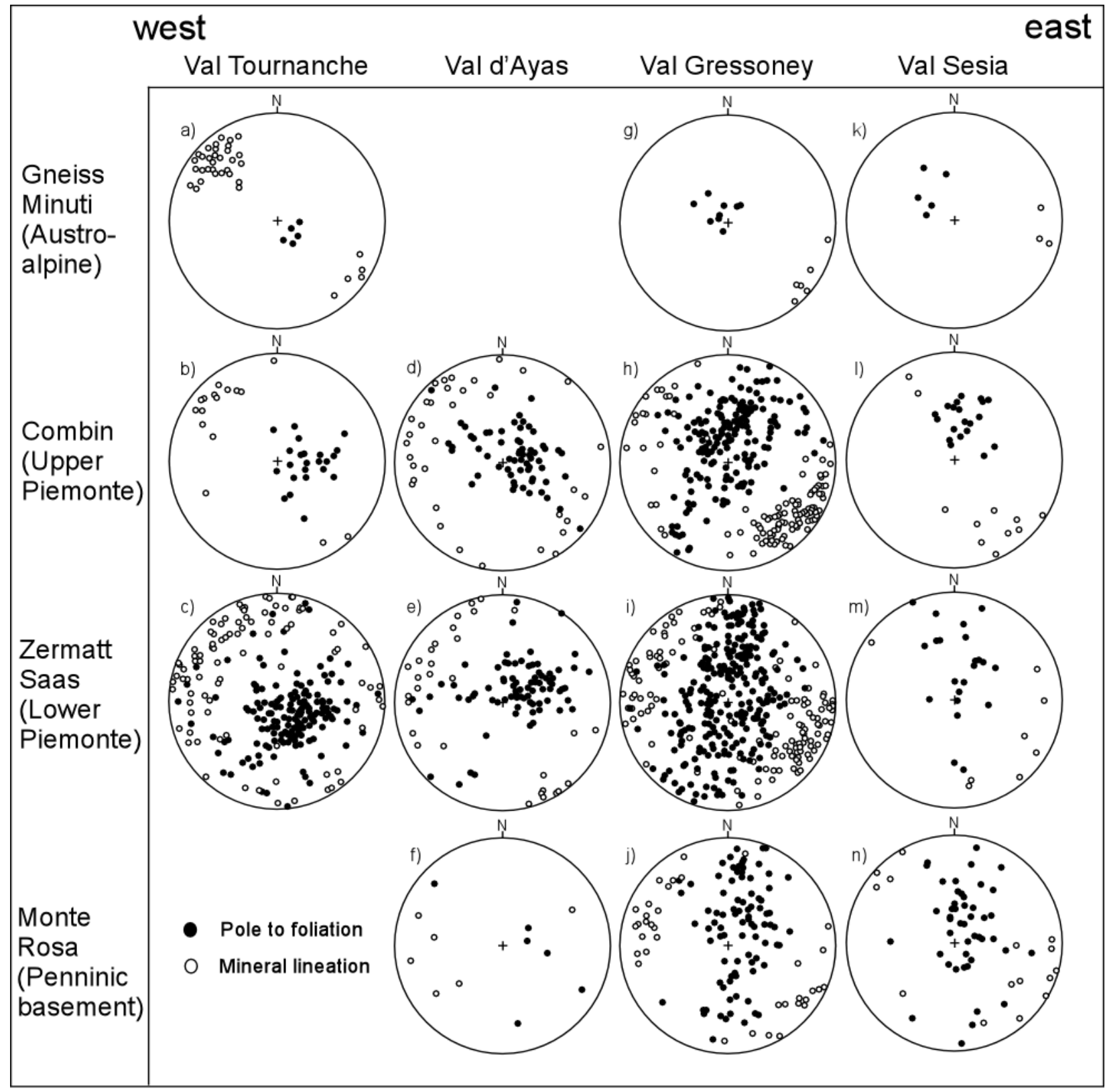

Reddy et al. / Tectonophysics

Figure 2 


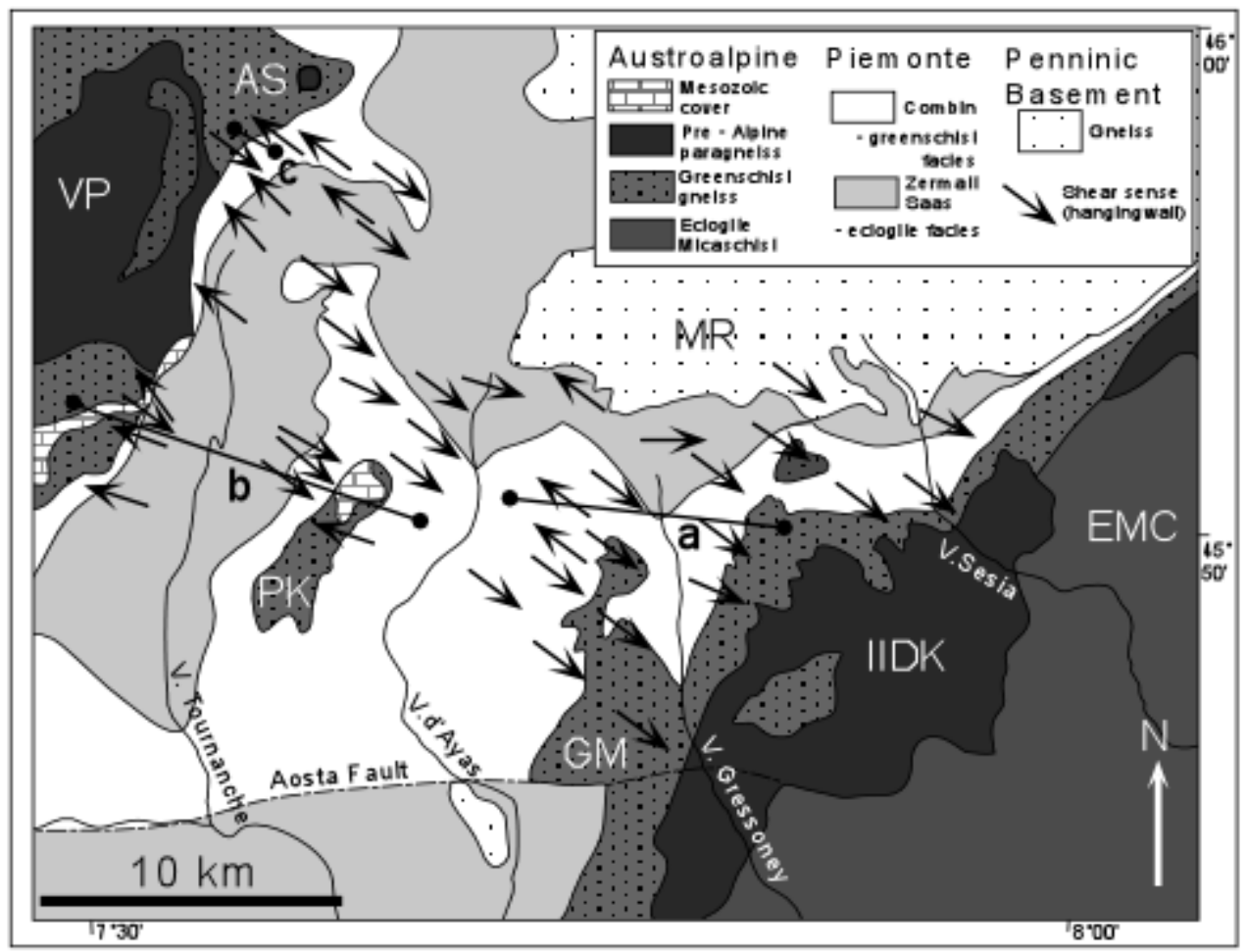

Reddy et al. / Tectonophysics

Figure 3 


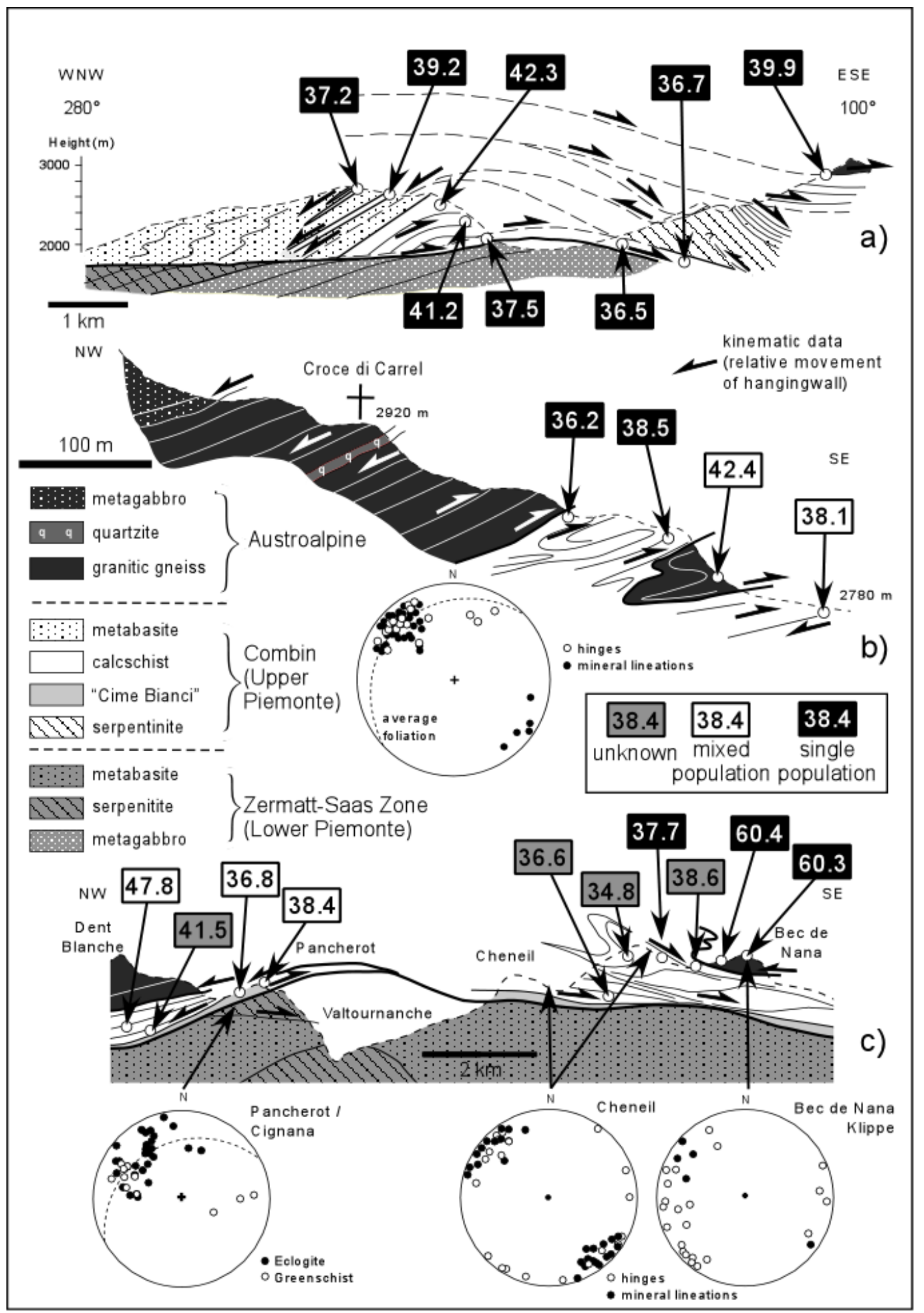

Reddy et al. / Tectonophysics

Figure 4 


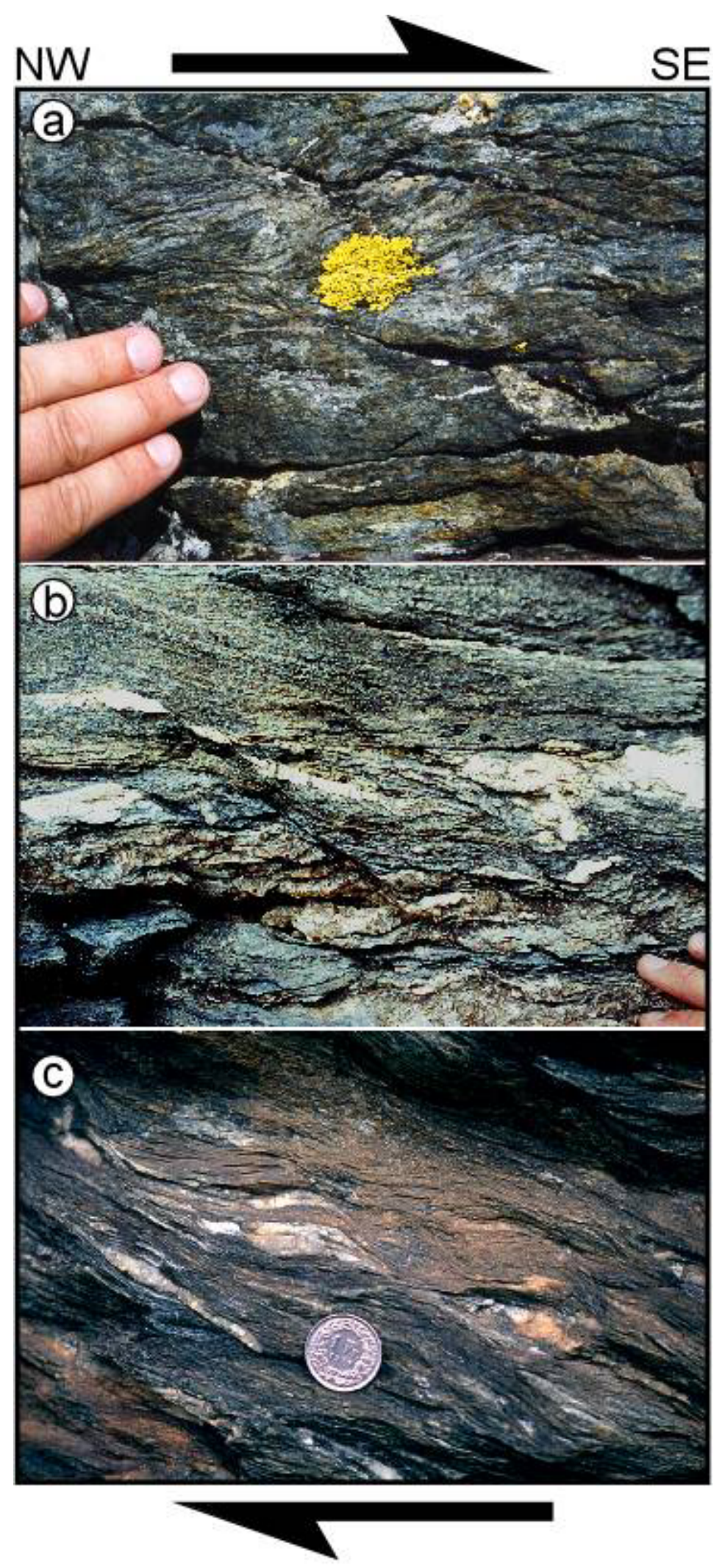

Reddy et al. / Tectonophysics

Figure 5 


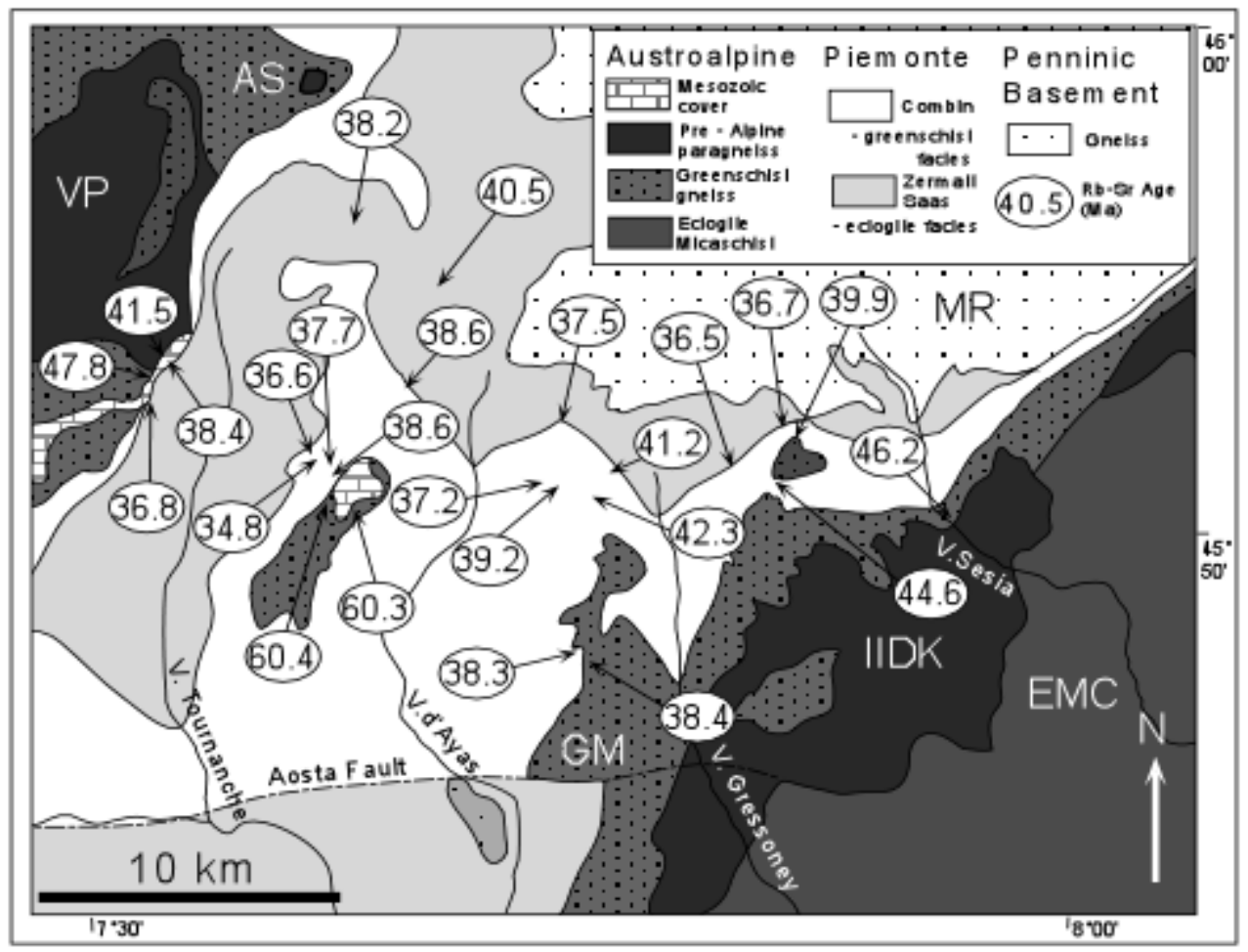

Reddy et al. / Tectonophysics

Figure 6 


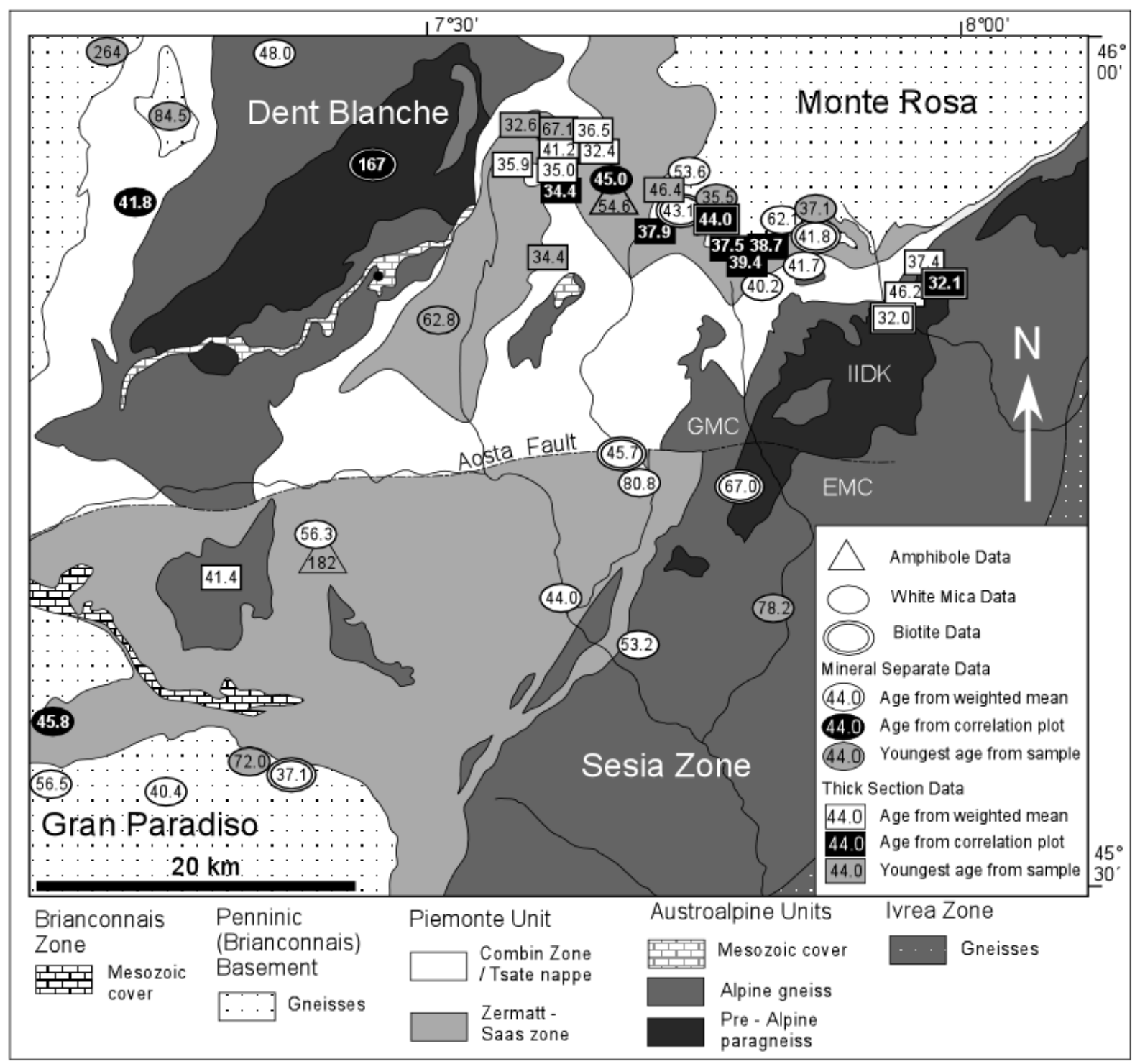

Reddy et al. / Tectonophysics

Figure 7 


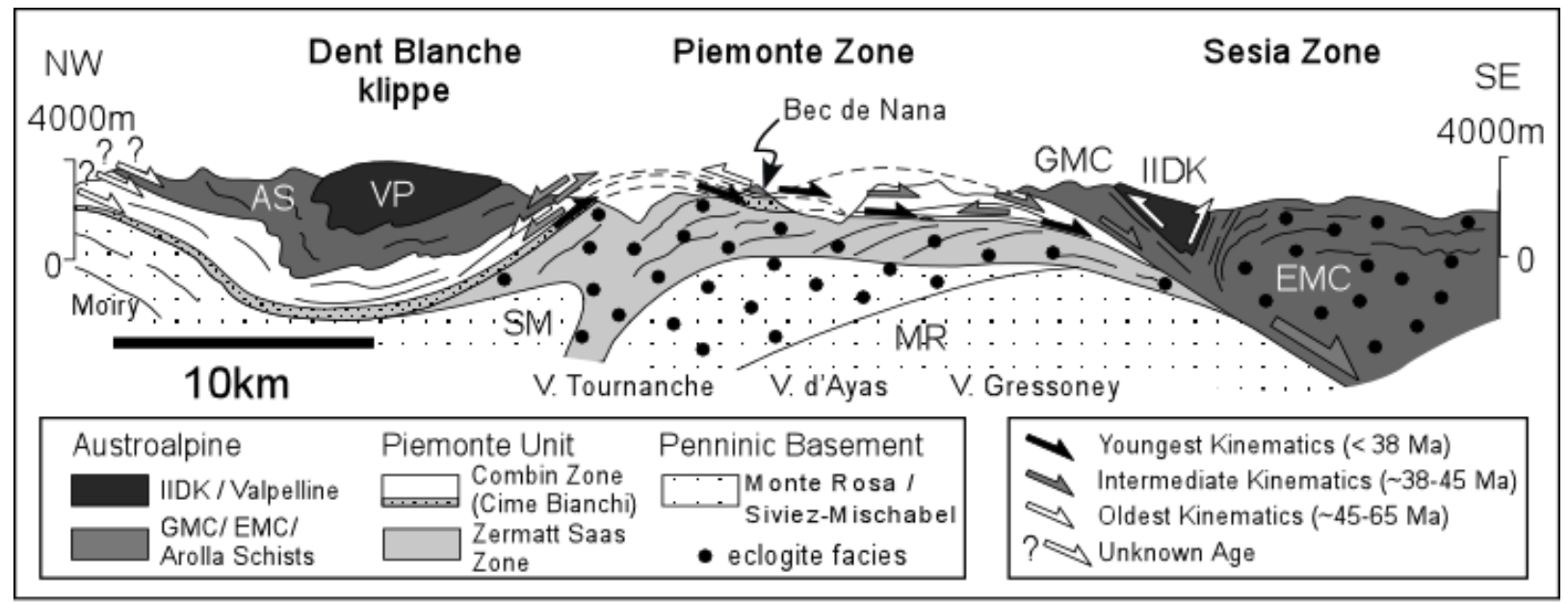

Reddy et al. / Tectonophysics

Figure 8 
Reddy et al/ Tectonophysics

Table 1

\begin{tabular}{|c|c|c|c|c|c|c|c|c|c|c|c|c|c|c|}
\hline Sample & Mineral & Rb ppm & Sr ppm & $\mathrm{Rb} / \mathrm{Sr}$ & ${ }^{87} \mathrm{Rb} /{ }^{86} \mathrm{Sr}$ & ${ }^{87} \mathrm{Sr} l^{86} \mathrm{Sr}$ & Mineral & Rb ppm & Sr ppm & $\mathrm{Rb} / \mathrm{Sr}$ & ${ }^{87} \mathrm{Rb} /{ }^{86} \mathrm{Sr}$ & ${ }^{87} \mathrm{Sr} l^{86} \mathrm{Sr}$ & Age & \pm \\
\hline 80175 & phengite & 265.8 & 13.5 & 19.64 & 57.05 & 0.74817 & feldspar & 26.1 & 39.2 & 0.67 & 1.93 & 0.71183 & 46.4 & 0.4 \\
\hline S3-28 & phengite & 390.2 & 11.6 & 33.61 & 97.83 & 0.76983 & epidote & 103.4 & 1681.1 & 0.06 & 0.18 & 0.71443 & 39.9 & 0.3 \\
\hline S3-30 & phengite & 7.6 & 3.8 & 2.02 & 5.84 & 0.71168 & tops 3.3 & 52.7 & 244.5 & 0.22 & 0.62 & 0.70902 & 35.8 & 1.3 \\
\hline S3-30 & phengite & 7.4 & 4.4 & 1.71 & 4.94 & 0.71128 & calcite & 2.5 & 471.9 & 0.01 & 0.02 & 0.70865 & 37.6 & 2.1 \\
\hline S3-30 & phengite & 7.4 & 4.4 & 1.71 & 4.94 & 0.71128 & feldspar & 8.1 & 351.5 & 0.02 & 0.07 & 0.70873 & 36.8 & 2.1 \\
\hline S3-44b & phengite & 373.4 & 84.1 & 4.44 & 12.85 & 0.71487 & calcite & 3.0 & 528.3 & 0.01 & 0.02 & 0.70810 & 37.1 & 0.5 \\
\hline S3-44b & phengite & 349.9 & 90.6 & 3.86 & 11.18 & 0.71412 & calcite & 0.1 & 489.8 & 0.00 & 0.00 & 0.70812 & 37.8 & 0.5 \\
\hline S3-74 & phengite & 363.0 & 13.1 & 27.77 & 80.71 & 0.75246 & calcite & 1.9 & 105.0 & 0.02 & 0.05 & 0.70819 & 38.6 & 0.3 \\
\hline S3-75b & phen/para & 30.8 & 108.1 & 0.28 & 0.82 & 0.70596 & epidote & 0.4 & 620.8 & 0.00 & 0.00 & 0.70539 & 48.8 & 6.5 \\
\hline S3-75b & phen/para & 155.4 & 75.1 & 2.07 & 5.98 & 0.70883 & epidote & 0.4 & 620.8 & 0.00 & 0.00 & 0.70539 & 40.5 & 0.6 \\
\hline 85354 & phengite & 500.5 & 2.7 & 185.37 & 556.93 & 1.10018 & feldspar & 5.5 & 11.5 & 0.48 & 1.39 & 0.72470 & 47.6 & 0.4 \\
\hline S4-60 & phengite & 445.8 & 62.3 & 7.16 & 20.75 & 0.72576 & 'carbonate' & 118.2 & 136.0 & 0.87 & 2.52 & 0.71346 & 47.5 & 0.5 \\
\hline S4-60 & phengite & 445.8 & 62.3 & 7.16 & 20.75 & 0.72576 & sphene & 22.6 & 39.9 & 0.57 & 1.64 & 0.71317 & 46.4 & 0.5 \\
\hline S5-04 & phengite & 420.6 & 173.7 & 2.42 & 7.01 & 0.71184 & calcite & 0.1 & 444.1 & 0.00 & 0.00 & 0.70813 & 37.2 & 0.5 \\
\hline S5-04 & phengite & 354.8 & 265.0 & 1.34 & 3.87 & 0.71043 & calcite & 0.3 & 407.5 & 0.00 & 0.00 & 0.70816 & 41.2 & 0.8 \\
\hline S5-41 & phengite & 372.0 & 16.8 & 22.20 & 64.50 & 0.75250 & epidote & 21.99 & 1644.9 & 0.01 & 0.039 & 0.71166 & 44.6 & 0.4 \\
\hline S5-42a & phengite & 229.6 & 216.1 & 1.06 & 3.07 & 0.70980 & calcite & 0.1 & 591.3 & 0.00 & 0.00 & 0.70796 & 42.3 & 1.8 \\
\hline S5-46a & phengite & 381.1 & 198.3 & 1.92 & 5.56 & 0.71103 & calcite & 0.1 & 581.8 & 0.00 & 0.00 & 0.70793 & 39.2 & 0.9 \\
\hline S5-48 & phengite & 433.6 & 127.8 & 3.39 & 9.82 & 0.71310 & calcite & 0.2 & 425.6 & 0.00 & 0.00 & 0.70802 & 36.5 & 0.4 \\
\hline S5-73 & phengite & 366.3 & 45.3 & 8.09 & 23.43 & 0.72181 & calcite & 24.0 & 489.8 & 0.05 & 0.14 & 0.70911 & 38.4 & 0.3 \\
\hline S5-73 & phengite & 366.3 & 45.3 & 8.09 & 23.43 & 0.72181 & calcite & 13.4 & 539.1 & 0.02 & 0.07 & 0.70921 & 38.0 & 0.3 \\
\hline S4-45 & phengite & 398.5 & 19.3 & 20.66 & 59.97 & 0.74111 & calcite & 88.6 & 201.7 & 0.44 & 1.27 & 0.71116 & 35.9 & 0.3 \\
\hline 58255 & phengite & 222.0 & 67.9 & 3.27 & 9.47 & 0.71425 & calcite & 0.1 & 783.5 & 0.00 & 0.00 & 0.70907 & 38.5 & 0.8 \\
\hline 58271 & phengite & 234.7 & 84.5 & 2.78 & 8.04 & 0.71329 & calcite & 0.1 & 58.4 & 0.00 & 0.00 & 0.70915 & 36.2 & 0.7 \\
\hline 58281 & phengite & 405.3 & 346.8 & 1.17 & 3.38 & 0.70964 & calcite & 0.0 & 185.2 & 0.00 & 0.00 & 0.70781 & 38.1 & 0.9 \\
\hline 58284 & phengite & 198.2 & 346.7 & 0.57 & 1.65 & 0.71075 & epidote & 23.2 & 1602.4 & 0.01 & 0.04 & 0.70978 & 42.4 & 1.3 \\
\hline 58290 & phengite & 198.2 & 47.3 & 4.19 & 12.15 & 0.71660 & calcite & 0.0 & 613.5 & 0.00 & 0.00 & 0.71111 & 31.8 & 0.6 \\
\hline 58285 & phengite & 118.7 & 146.0 & 0.81 & 2.35 & 0.70962 & calcite & 0.2 & 56.5 & 0.00 & 0.01 & 0.70803 & 47.8 & 1.2 \\
\hline 58257 & phengite & 318.6 & 5.9 & 54.00 & 156.77 & 0.79355 & calcite & 0.0 & 1190.3 & 0.00 & 0.00 & 0.70798 & 38.4 & 0.8 \\
\hline 58292 & phengite & 152.0 & 218.4 & 0.70 & 2.01 & 0.70957 & calcite & 0.4 & 365.5 & 0.00 & 0.00 & 0.70839 & 41.5 & 1.2 \\
\hline 58288 & phengite & 356.0 & 90.8 & 3.92 & 11.35 & 0.71371 & calcite & 0.1 & 920.7 & 0.00 & 0.00 & 0.70779 & 36.8 & 0.7 \\
\hline 58259 & phengite & 299.4 & 7.4 & 40.46 & 118.27 & 0.77248 & calcite & 0.1 & 211.8 & 0.00 & 0.00 & 0.71462 & 34.8 & 0.6 \\
\hline 58277 & phengite & 413.8 & 77.9 & 5.31 & 15.38 & 0.71922 & calcite & 0.1 & 14.2 & 0.01 & 0.03 & 0.71080 & 38.6 & 0.8 \\
\hline 58280 & phengite & 317.8 & 44.4 & 7.16 & 20.74 & 0.72130 & calcite & 0.2 & 239.1 & 0.00 & 0.00 & 0.71051 & 36.6 & 0.6 \\
\hline 58287 & phengite & 389.4 & 90.7 & 4.29 & 12.44 & 0.72056 & calcite & 16.5 & 117.2 & 0.14 & 0.41 & 0.71412 & 37.7 & 0.8 \\
\hline 58275 & phengite & 393.7 & 4.0 & 98.43 & 291.01 & 0.95796 & calcite & 2.0 & 278.9 & 0.01 & 0.02 & 0.70876 & 60.3 & 1.2 \\
\hline 58276 & phengite & 389.8 & 4.3 & 90.65 & 268.10 & 0.93938 & calcite & 3.6 & 323.6 & 0.01 & 0.03 & 0.70952 & 60.4 & 1.2 \\
\hline
\end{tabular}




\begin{tabular}{|c|c|c|c|c|}
\hline Sample & Unit & Age & +- & Excess Ar \\
\hline 55020 wm & EMC & 62.8 & 1.2 & $?$ \\
\hline 55044 wm & EMC & 77.9 & 1.2 & yes \\
\hline 55045 wm & EMC & 95.9 & 1.7 & yes \\
\hline 56128 wm & EMC & 90.8 & 1.8 & yes \\
\hline 56136 wm & EMC & 112.4 & 1.3 & yes \\
\hline S3-18 wm & EMC & 62.8 & 1.3 & $?$ \\
\hline S3-59 amp & EMC & 330.1 & 5.7 & yes \\
\hline S3-59 wm & EMC & 78.2 & 0.8 & yes \\
\hline S3-28 wm & GMC & 41.7 & 0.4 & possible \\
\hline S3-58 wm & GMC & 53.2 & 0.5 & probable \\
\hline J3-20 wm & AS & 48.0 & 0.5 & $?$ \\
\hline J3-38 wm & $\mathrm{CO}$ & 41.8 & 1.5 & No \\
\hline S3-38 wm & $\mathrm{CO}$ & 40.2 & 0.4 & $?$ \\
\hline J3-39 wm & ZS & 45.8 & 6.8 & hom. XS \\
\hline J3-48 amp & ZS & 181.7 & 16.9 & yes \\
\hline J3-48 wm & ZS & 56.3 & 2.0 & $?$ \\
\hline J3-50 wm & ZS & 44.0 & 0.5 & $?$ \\
\hline S3-75b amp & ZS & 54.6 & 9.8 & yes \\
\hline S3-75b wm & ZS & 45.0 & 1.6 & hom.XS (slight) \\
\hline S3-46d wm & MR & 62.1 & 0.4 & possible \\
\hline S3-57b bte & MR & 45.7 & 0.7 & $?$ \\
\hline S3-57b wm & MR & 80.8 & 0.7 & $?$ \\
\hline S3-69 bte & MR & 54.3 & 0.8 & $?$ \\
\hline S3-69 wm & MR & 53.6 & 1.0 & yes \\
\hline J3-04 bte & GP & 37.1 & 0.7 & $?$ \\
\hline J3-04 wm & GP & 72.0 & 1.4 & yes \\
\hline J3-42 wm & GP & 56.5 & 1.8 & yes \\
\hline J3-45 wm & GP & 40.4 & 0.4 & $?$ \\
\hline J3-16 wm & GSB & 84.5 & 0.9 & ? but possible \\
\hline J3-17 wm & GSB & 264.4 & 2.8 & ? probable \\
\hline J3-41 wm & GSB & 82.0 & 15.0 & $?$ \\
\hline
\end{tabular}

Black text $=$ weighted mean ages Black Text (Italics) = ages from correlation diagram Boxes indicate excess corrected age 


\begin{tabular}{|c|c|c|c|c|}
\hline Sample & Unit & Age & +- & Comment \\
\hline S4-12a bte & lamprophyre & 27.5 & 0.5 & Excess \\
\hline J3-35 Bte & VP & 184.2 & 0.7 & Variable excess \\
\hline J3-35 Bte & VP & 167.0 & 6.0 & Variable excess \\
\hline 80170 wm & EMC & 41.4 & 0.5 & possible excess \\
\hline 80192 amph & EMC & 102.7 & 4.7 & Variable excess \& loss \\
\hline 80175 bte & GMC & 32.1 & 1.1 & No excess \\
\hline 80175 wm & GMC & 37.4 & 4.8 & probable Excess \\
\hline 80176 bte & GMC & 32.0 & 0.5 & Can't assess excess \\
\hline 80176 wm & GMC & 46.2 & 0.5 & probable Excess \\
\hline J3-27 amp & GMC & 315.4 & 10.6 & Excess \\
\hline S3-74 wm & Co & 34.4 & 1.2 & No excess \\
\hline S4-41 wm & Co & 41.2 & 0.6 & Can't assess excess \\
\hline S4-41 wm & Co & 41.3 & 0.6 & Can't assess excess \\
\hline S3-24 & Co base & 34.4 & 2.1 & Excess in rims \\
\hline S3-24 & Co base & 37.4 & 0.4 & Excess in rims \\
\hline S4-03a wm & ZS & 39.4 & 3.1 & Excess \\
\hline S4-03c wm & ZS & 37.5 & 1.1 & Excess \\
\hline S4-14 wm & ZS & 67.1 & 9.7 & probable Excess \\
\hline S4-45 wm & ZS & 32.4 & 1.3 & Excess \\
\hline 85050 wm & ZS & 44.0 & 1.4 & Excess \\
\hline S3-49 wm & ZS & 38.7 & 2.0 & Excess \\
\hline S4-60 wm & ZS & 27.6 & 5.8 & Range of ages \\
\hline S4-60 wm & ZS & 45.0 & 3.0 & Cores older then rims \\
\hline S3-84b wm & ZS & 37.9 & 1.5 & No excess \\
\hline S5-73 wm & ZS & 35.9 & 1.8 & Excess \\
\hline S4-26 wm & ZS & 36.5 & 2.8 & No excess \\
\hline S3-72 wm & MR & 46.4 & 0.7 & wt mean of 4 single grain analyses \\
\hline S3-69 bte & MR & 43.1 & 7.0 & Excess \\
\hline S3-46d wm & MR & 37.1 & 7.0 & Range of ages \\
\hline S3-46d wm & MR & 54.3 & 7.2 & Cores older then rims \\
\hline S3-46d bte & MR & 41.8 & 1.6 & possible excess \\
\hline
\end{tabular}

Black text $=$ weighted mean

Black Text (Italics) = ages from correlation diagram

Boxes indicate excess corrected age

Grey = youngest age from the data set 
White Mica Data

\begin{tabular}{|c|c|c|c|c|c|c|c|c|c|c|c|c|c|c|c|}
\hline Sample & Unit & $\left.{ }^{40} \mathrm{Ar}\right|^{33} \mathrm{Ar}$ & + & 列 ${ }^{3{ }^{39} \mathrm{Ar}}$ & + & ${ }^{37} \mathrm{Ar} /{ }^{39} \mathrm{Ar}$ & + & ${ }^{36} \mathrm{Ar} \mathbf{r}^{39} \mathrm{Ar}$ & + & Total ${ }^{39} \mathrm{Ar}$ & + & ${ }^{40} \mathrm{Ar} * /^{39} \mathrm{Ar}$ & +- & Age (Ma) & + \\
\hline \multicolumn{16}{|c|}{ Austroalpine } \\
\hline $\begin{array}{l}55020 \mathrm{wm} \\
55020 \mathrm{wm}\end{array}$ & EMC & $\begin{array}{l}6.59523 \\
5.67083\end{array}$ & $\begin{array}{l}0.13251 \\
0.05080\end{array}$ & $\begin{array}{l}0.03243 \\
0.02069\end{array}$ & $\begin{array}{l}0.00206 \\
0.00067\end{array}$ & $\begin{array}{l}0.11580 \\
0.11712\end{array}$ & $\begin{array}{l}0.00691 \\
0.00326\end{array}$ & $\begin{array}{l}0.00390 \\
0.00075\end{array}$ & $\begin{array}{l}0.00062 \\
0.00031\end{array}$ & $\begin{array}{l}0.54299 \\
0.74383\end{array}$ & $\begin{array}{l}0.00935 \\
0.00632\end{array}$ & $\begin{array}{l}5.44258 \\
5.44974\end{array}$ & $\begin{array}{l}0.21470 \\
0.10419\end{array}$ & $\begin{array}{l}62.7 \\
62.8\end{array}$ & $\begin{array}{l}2.4 \\
1.2\end{array}$ \\
\hline $\begin{array}{l}55044 \mathrm{wm} \\
55044 \mathrm{wm}\end{array}$ & EMC & $\begin{array}{l}9.02305 \\
9.04834\end{array}$ & $\begin{array}{l}0.06689 \\
0.06504\end{array}$ & $\begin{array}{l}0.02757 \\
0.03920\end{array}$ & $\begin{array}{l}0.00094 \\
0.00183\end{array}$ & $\begin{array}{l}0.12816 \\
0.24994\end{array}$ & $\begin{array}{l}0.00229 \\
0.00500\end{array}$ & $\begin{array}{l}0.00758 \\
0.00594\end{array}$ & $\begin{array}{l}0.00031 \\
0.00077\end{array}$ & $\begin{array}{l}1.58983 \\
0.38798\end{array}$ & $\begin{array}{l}0.00918 \\
0.00262\end{array}$ & $\begin{array}{l}6.78435 \\
7.29263\end{array}$ & $\begin{array}{l}0.10629 \\
0.23410\end{array}$ & $\begin{array}{l}77.9 \\
83.6\end{array}$ & $\begin{array}{l}1.2 \\
2.6\end{array}$ \\
\hline $\begin{array}{l}55045 \mathrm{wm} \\
55045 \mathrm{wm}\end{array}$ & EMC & $\begin{array}{l}9.74388 \\
8.83881\end{array}$ & $\begin{array}{l}0.22004 \\
0.11572\end{array}$ & $\begin{array}{l}0.01728 \\
0.01918\end{array}$ & $\begin{array}{l}0.00097 \\
0.00118\end{array}$ & $\begin{array}{l}0.07992 \\
0.02216\end{array}$ & $\begin{array}{l}0.00299 \\
0.00243\end{array}$ & $\begin{array}{l}0.00381 \\
0.00150\end{array}$ & $\begin{array}{l}0.00029 \\
0.00031\end{array}$ & $\begin{array}{l}0.93979 \\
0.51851\end{array}$ & $\begin{array}{l}0.01577 \\
0.00545\end{array}$ & $\begin{array}{l}8.61896 \\
8.39669\end{array}$ & $\begin{array}{l}0.22221 \\
0.14520\end{array}$ & $\begin{array}{l}98.3 \\
95.9\end{array}$ & $\begin{array}{l}2.5 \\
1.7\end{array}$ \\
\hline $\begin{array}{l}56128 \mathrm{wm} \\
56128 \mathrm{wm}\end{array}$ & EMC & $\begin{array}{l}8.31379 \\
9.30770\end{array}$ & $\begin{array}{l}0.10914 \\
0.09464\end{array}$ & $\begin{array}{l}0.01516 \\
0.01982\end{array}$ & $\begin{array}{l}0.00162 \\
0.00054\end{array}$ & $\begin{array}{l}0.06325 \\
0.00876\end{array}$ & $\begin{array}{l}0.00433 \\
0.00109\end{array}$ & $\begin{array}{l}0.00125 \\
0.00172\end{array}$ & $\begin{array}{l}0.00039 \\
0.00028\end{array}$ & $\begin{array}{l}0.41235 \\
1.53448\end{array}$ & $\begin{array}{l}0.00465 \\
0.01238\end{array}$ & $\begin{array}{l}7.94451 \\
8.79913\end{array}$ & $\begin{array}{l}0.15529 \\
0.12295\end{array}$ & $\begin{array}{c}90.8 \\
100.3\end{array}$ & $\begin{array}{l}1.8 \\
1.4\end{array}$ \\
\hline $\begin{array}{l}56136 \mathrm{wm} \\
56136 \mathrm{wm}\end{array}$ & EMC & $\begin{array}{l}11.20882 \\
10.11434\end{array}$ & $\begin{array}{l}0.06453 \\
0.06784\end{array}$ & $\begin{array}{l}0.02530 \\
0.02021\end{array}$ & $\begin{array}{l}0.00065 \\
0.00040\end{array}$ & $\begin{array}{l}0.41843 \\
0.01194\end{array}$ & $\begin{array}{l}0.00239 \\
0.00124\end{array}$ & $\begin{array}{l}0.00389 \\
0.00075\end{array}$ & $\begin{array}{l}0.00056 \\
0.00029\end{array}$ & $\begin{array}{l}0.44869 \\
0.75311\end{array}$ & $\begin{array}{l}0.00212 \\
0.00448\end{array}$ & $\begin{array}{c}10.05941 \\
9.89413\end{array}$ & $\begin{array}{l}0.17609 \\
0.10850\end{array}$ & $\begin{array}{l}114.3 \\
112.4\end{array}$ & $\begin{array}{l}2.0 \\
1.3\end{array}$ \\
\hline $\begin{array}{l}\text { S3-18 wm } \\
\text { S3-18 wm }\end{array}$ & EMC & $\begin{array}{l}6.48413 \\
5.61770\end{array}$ & $\begin{array}{l}0.03527 \\
0.04353\end{array}$ & $\begin{array}{l}0.01700 \\
0.02227\end{array}$ & $\begin{array}{l}0.00047 \\
0.00103\end{array}$ & $\begin{array}{l}0.00613 \\
0.02301\end{array}$ & $\begin{array}{l}0.00102 \\
0.00337\end{array}$ & $\begin{array}{l}0.00161 \\
0.00056\end{array}$ & $\begin{array}{l}0.00017 \\
0.00035\end{array}$ & $\begin{array}{l}2.58218 \\
0.84155\end{array}$ & $\begin{array}{l}0.00934 \\
0.00555\end{array}$ & $\begin{array}{l}6.00767 \\
5.45277\end{array}$ & $\begin{array}{l}0.05951 \\
0.11133\end{array}$ & $\begin{array}{l}69.1 \\
62.8\end{array}$ & $\begin{array}{l}0.7 \\
1.3\end{array}$ \\
\hline $\begin{array}{l}\text { S3-59 wm } \\
\text { S3-59 wm }\end{array}$ & EMC & $\begin{array}{l}7.01424 \\
7.53374\end{array}$ & $\begin{array}{l}0.05455 \\
0.08203\end{array}$ & $\begin{array}{l}0.01598 \\
0.02042\end{array}$ & $\begin{array}{l}0.00042 \\
0.00066\end{array}$ & $\begin{array}{l}0.00256 \\
0.00693\end{array}$ & $\begin{array}{l}0.00046 \\
0.00163\end{array}$ & $\begin{array}{l}0.00068 \\
0.00262\end{array}$ & $\begin{array}{l}0.00012 \\
0.00043\end{array}$ & $\begin{array}{l}2.53144 \\
0.44971\end{array}$ & $\begin{array}{l}0.00866 \\
0.00324\end{array}$ & $\begin{array}{l}6.81457 \\
6.76099\end{array}$ & $\begin{array}{l}0.06534 \\
0.15019\end{array}$ & $\begin{array}{l}78.2 \\
77.6\end{array}$ & $\begin{array}{l}0.8 \\
1.7\end{array}$ \\
\hline $\begin{array}{l}\text { S3-28 wm } \\
\text { S3-28 wm } \\
\text { S3-28 wm } \\
\text { S3-28 wm }\end{array}$ & GMC & $\begin{array}{l}3.71480 \\
3.70750 \\
4.04531 \\
4.31186\end{array}$ & $\begin{array}{l}0.02397 \\
0.02807 \\
0.10261 \\
0.15699\end{array}$ & $\begin{array}{l}0.01680 \\
0.01364 \\
0.01331 \\
0.01669\end{array}$ & $\begin{array}{l}0.00030 \\
0.00017 \\
0.00032 \\
0.00042\end{array}$ & $\begin{array}{l}0.04837 \\
0.00398 \\
0.12078 \\
0.01206\end{array}$ & $\begin{array}{l}0.00140 \\
0.00056 \\
0.00316 \\
0.00084\end{array}$ & $\begin{array}{l}0.00128 \\
0.00029 \\
0.00027 \\
0.00139\end{array}$ & $\begin{array}{l}0.00022 \\
0.00011 \\
0.000099 \\
0.00022\end{array}$ & & $\begin{array}{l}0.00851 \\
0.00683 \\
0.04601 \\
0.00892\end{array}$ & & $\begin{array}{l}0.06945 \\
0.04220 \\
0.10509 \\
0.16905\end{array}$ & $\begin{array}{l}38.7 \\
42.0 \\
45.9 \\
45.2\end{array}$ & $\begin{array}{l}0.8 \\
0.5 \\
1.2 \\
1.9\end{array}$ \\
\hline $\begin{array}{l}\text { S3-58 wm } \\
\text { S3-58 wm }\end{array}$ & GMC & $\begin{array}{l}4.75274 \\
4.40567\end{array}$ & $\begin{array}{l}0.02369 \\
0.04952\end{array}$ & $\begin{array}{l}0.01545 \\
0.02061\end{array}$ & $\begin{array}{l}0.00022 \\
0.00108\end{array}$ & $\begin{array}{l}0.01129 \\
0.01890\end{array}$ & $\begin{array}{l}0.00056 \\
0.00244\end{array}$ & $\begin{array}{l}0.00044 \\
0.00013\end{array}$ & $\begin{array}{l}0.00011 \\
0.00047\end{array}$ & $\begin{array}{l}2.63512 \\
0.55119\end{array}$ & $\begin{array}{l}0.01128 \\
0.00602\end{array}$ & $\begin{array}{l}4.62192 \\
4.36718\end{array}$ & $\begin{array}{l}0.03929 \\
0.14735\end{array}$ & $\begin{array}{l}53.4 \\
50.5\end{array}$ & $\begin{array}{l}0.5 \\
1.7\end{array}$ \\
\hline $\begin{array}{l}\mathrm{J3}-20 \mathrm{wm} \\
\mathrm{J3}-20 \mathrm{wm} \\
\mathrm{J} 3-20 \mathrm{wm} \\
\mathrm{J3}-20 \mathrm{wm}\end{array}$ & AS & $\begin{array}{l}4.44266 \\
4.40902 \\
4.18179 \\
4.34775\end{array}$ & & & & & & & $\begin{array}{l}0.00037 \\
0.00011 \\
0.00021 \\
0.00033\end{array}$ & & & & & $\begin{array}{l}46.9 \\
48.3 \\
47.7 \\
48.4\end{array}$ & $\begin{array}{l}1.3 \\
0.6 \\
0.9 \\
1.3\end{array}$ \\
\hline \multicolumn{16}{|c|}{ Piemonte Unit } \\
\hline & co & $\begin{array}{l}5.55631 \\
4.19838 \\
4.34804 \\
4.06280\end{array}$ & & & & & & $\begin{array}{c}0.00691 \\
0.002027 \\
0.00241 \\
\text { n.d. }\end{array}$ & $\begin{array}{c}0.00154 \\
0.000072 \\
0.00055 \\
\text { n.d. }\end{array}$ & & & & & $\begin{array}{l}40.7 \\
41.6 \\
42.1 \\
47.3\end{array}$ & $\begin{array}{l}5.3 \\
2.5 \\
2.0 \\
1.4\end{array}$ \\
\hline $\begin{array}{l}\text { S3-38 wm } \\
\text { S3-38 wm } \\
\text { s3-38 wm } \\
\text { S3-38 wm }\end{array}$ & Co & $\begin{array}{l}3.67753 \\
3.44494 \\
3.35240 \\
3.23906\end{array}$ & $\begin{array}{l}0.03063 \\
0.08366 \\
0.04964 \\
0.04380\end{array}$ & & $\begin{array}{l}0.00025 \\
0.00087 \\
0.00023 \\
0.00057\end{array}$ & & $\begin{array}{l}0.00050 \\
0.00159 \\
0.00071 \\
0.00222\end{array}$ & $\begin{array}{c}0.00015 \\
\text { n.d. } \\
0.00016 \\
\text { n.d. }\end{array}$ & $\begin{array}{c}0.00013 \\
\text { n.d. } \\
0.00009 \\
\text { n.d. }\end{array}$ & $\begin{array}{l}5.82937 \\
1.76516 \\
2.36146 \\
0.73188\end{array}$ & & $\begin{array}{l}3.63193 \\
3.47514 \\
3.30595 \\
3.37192\end{array}$ & & $\begin{array}{l}42.1 \\
40.3 \\
38.4 \\
39.1\end{array}$ & $\begin{array}{l}0.6 \\
1.2 \\
0.7 \\
0.9\end{array}$ \\
\hline & zs & & & & & & & & & & & & & & $\begin{array}{c}13.6 \\
7.9 \\
6.9 \\
4.5\end{array}$ \\
\hline \begin{tabular}{|l} 
J3-48 wm \\
J3-48 wm
\end{tabular} & zs & $\begin{array}{l}8.14272 \\
8.46720\end{array}$ & & & & & 0.00902 & & & & & & & & $\begin{array}{r}11.3 \\
2.0\end{array}$ \\
\hline \begin{tabular}{|l}
$\mathbf{J 3}-50 \mathrm{wm}$ \\
\\
J3-50 wm
\end{tabular} & zs & & & & & & & & & & & & & & $\begin{array}{l}0.8 \\
0.6\end{array}$ \\
\hline & zs & & & & & & & & & & & & & & $\begin{array}{l}2.4 \\
2.9 \\
1.1 \\
0.9\end{array}$ \\
\hline \multicolumn{16}{|c|}{ Pennine Basement } \\
\hline & MR & & & & & & & & & & & & & & $\begin{array}{l}0.6 \\
0.9 \\
0.6 \\
0.8\end{array}$ \\
\hline & MR & & & & & & & & & & & & & & $\begin{array}{l}3.2 \\
1.7 \\
1.0 \\
1.3\end{array}$ \\
\hline & MR & & & & & & & $\begin{array}{c}0.00081 \\
\text { n.d. } \\
0.00054 \\
0.00158\end{array}$ & & & & & & & $\begin{array}{l}1.0 \\
1.0 \\
0.8 \\
1.1\end{array}$ \\
\hline & GP & & & & & & & & & & & & & & $\begin{array}{l}1.4 \\
2.3 \\
2.0 \\
0.8\end{array}$ \\
\hline $\begin{array}{l}\text { J3-42 wm } \\
\text { J3-42 wm }\end{array}$ & GP & $\begin{array}{c}5.09375 \\
12.02797\end{array}$ & $\begin{array}{l}0.13940 \\
0.24693\end{array}$ & $\begin{array}{l}0.01917 \\
0.01897\end{array}$ & $\begin{array}{l}0.00109 \\
0.00075\end{array}$ & $\begin{array}{l}0.01195 \\
0.01021\end{array}$ & $\begin{array}{l}0.00242 \\
0.00257\end{array}$ & $\begin{array}{c}0.00067 \\
\text { n.d. }\end{array}$ & $\begin{array}{c}0.00028 \\
\text { n.d. }\end{array}$ & $\begin{array}{l}0.96278 \\
0.63806\end{array}$ & $\begin{array}{l}0.01968 \\
0.00843\end{array}$ & $\begin{array}{c}4.89505 \\
12.11312\end{array}$ & $\begin{array}{l}.15959 \\
.26140\end{array}$ & $\begin{array}{c}56.5 \\
136.7\end{array}$ & $\begin{array}{l}1.8 \\
2.9\end{array}$ \\
\hline \begin{tabular}{|l} 
J3-45 wm \\
J3-45 wm
\end{tabular} & GP & $\begin{array}{l}3.66886 \\
3.69245\end{array}$ & $\begin{array}{l}0.03065 \\
0.03715\end{array}$ & $\begin{array}{l}0.01417 \\
0.01496\end{array}$ & 0.00047 & 0.00528 & $\begin{array}{l}0.00116 \\
0.00083\end{array}$ & $\begin{array}{l}0.00081 \\
0.00046\end{array}$ & 0.00014 & & & $\begin{array}{l}3.42847 \\
3.55657\end{array}$ & $\begin{array}{l}0.04769 \\
0.05488\end{array}$ & $\begin{array}{l}39.8 \\
41.2\end{array}$ & $\begin{array}{l}0.6 \\
0.7\end{array}$ \\
\hline $\begin{array}{l}\text { J3-16 wm } \\
\text { J3-16 wm }\end{array}$ & GSB & $\begin{array}{c}11.41802 \\
7.38925\end{array}$ & & $\begin{array}{l}0.01806 \\
0.01658\end{array}$ & & & $\begin{array}{l}0.00150 \\
0.00169\end{array}$ & $\begin{array}{l}0.00093 \\
0.00004\end{array}$ & $\begin{array}{l}0.00025 \\
0.00018\end{array}$ & $\begin{array}{l}0.98536 \\
0.63224\end{array}$ & & $\begin{array}{c}11.14283 \\
7.37608\end{array}$ & $\begin{array}{l}0.34457 \\
0.07224\end{array}$ & $\begin{array}{c}126.2 \\
84.5\end{array}$ & $\begin{array}{l}3.8 \\
0.9\end{array}$ \\
\hline $\begin{array}{l}J 3-17 \text { wm } \\
\text { J3-17 wm }\end{array}$ & GSB & $\begin{array}{l}24.94255 \\
23.66258\end{array}$ & 0.20001 & .02383 & & 0.03523 & 0.00198 & & & 0.90994 & $\begin{array}{l}0.00313 \\
0.00723\end{array}$ & 24.28274 & $\begin{array}{l}0.31012 \\
0.25092\end{array}$ & $\begin{array}{l}272.9 \\
264.4\end{array}$ & $\begin{array}{l}3.3 \\
2.8\end{array}$ \\
\hline $\begin{array}{l}\text { J3-41 wm } \\
\text { J3-41 wm }\end{array}$ & GSB & $\begin{array}{l}10.48993 \\
10.35103\end{array}$ & 0.50722 & 0.20999 & 0.01739 & 0.95158 & $\begin{array}{l}0.05948 \\
0.07135\end{array}$ & 0.01082 & 0.00440 & 0.07315 & 0.00345 & $\begin{array}{l}9.32035 \\
7.15385\end{array}$ & $\begin{array}{l}0.35264 \\
1.34210\end{array}$ & $\begin{array}{l}106.1 \\
82.0\end{array}$ & $\begin{array}{c}3.9 \\
15.0\end{array}$ \\
\hline
\end{tabular}

Biotite Data

\begin{tabular}{|c|c|c|c|c|c|c|c|c|c|c|c|c|c|c|c|}
\hline Sample & Unit & $\left.{ }^{40} \mathrm{Ar}\right]^{39} \mathrm{Ar}$ & +- & ${ }^{38} \mathrm{Ar}{ }^{3{ }^{3}} \mathrm{Ar}$ & + & ${ }^{37} \mathrm{Ar}{ }^{3{ }^{3} \mathrm{Ar}}$ & + & ${ }^{36} \mathrm{Ar}{ }^{3{ }^{3}} \mathrm{Ar}$ & +- & Total ${ }^{39} \mathrm{Ar}$ & + & ${ }^{40} \mathrm{Ar} \mathbf{r}^{* 3{ }^{39}} \mathrm{Ar}$ & +- & Age (Ma) & + \\
\hline \multicolumn{16}{|c|}{ Pennine Basement } \\
\hline 33-57b bte & MR & 4.09175 & 0.05620 & 0.03048 & 0.00157 & 0.04136 & 0.00464 & 0.00075 & 0.00015 & 0.94400 & 0.00894 & 3.87081 & 0.07099 & 44.8 & 0.8 \\
\hline & & 4.276 & 04667 & 0.03 & 0. & $\mathrm{n} \cdot \mathrm{c}$ & n.d. & & & & & & & & 1.2 \\
\hline & & 9.08503 & 0.06428 & 0.03 & 0.00155 & 0.16 & & $0.01 \mathrm{c}$ & 0.00 & & & & & & 3.1 \\
\hline S3-57b bte & & 6.39143 & 0.05419 & 0.04061 & 0.00187 & 0.02413 & 0.00845 & 0.01019 & 0.00089 & 0.81032 & 0.00349 & 3.38069 & 0.26638 & 39.2 & 3.1 \\
\hline $69 \mathrm{bt}$ & MR & 4.90021 & 0.09075 & 074 & 0.00147 & 0.13217 & 0.00563 & 0.0007 & 0.00023 & 1.39490 & 0.01944 & 4.69168 & 0.11141 & 54. & 1.3 \\
\hline S3-69 bte & & 4.76846 & 0.08814 & 0.08018 & 0.00182 & 0.03999 & 0.00106 & 0.00020 & 0.00010 & 1.97124 & 0.03123 & 4.71063 & 0.09197 & 54.4 & 1.1 \\
\hline S3-04 bte & GP & 3.60971 & 0.02485 & 0.04978 & 0.00241 & 0.01078 & 0.00330 & 0.00194 & 0.00060 & 0.20655 & 0.00094 & 3.03775 & 0.17910 & 35.3 & 2.1 \\
\hline
\end{tabular}

Amphibole Data

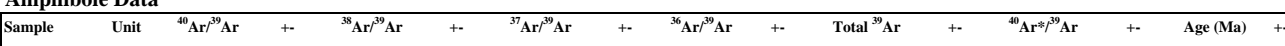

Austroalpine

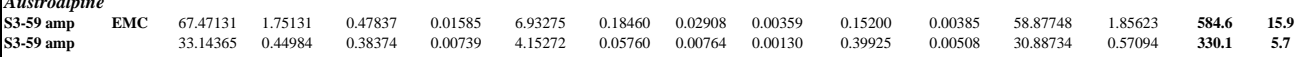
Piemonte Unit

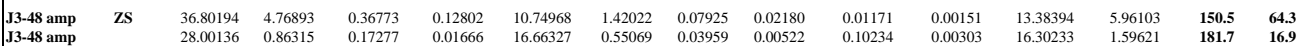

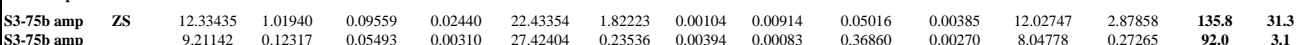

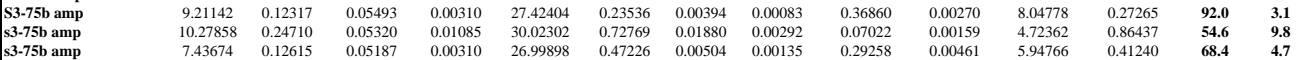

Volume of total ${ }^{39} \mathrm{Ar}$ measured $=$ 'value' $\times 10^{-10} \mathrm{~cm}^{3}$ STP

JVactor, Michign, USA

n.d. $=$ not determine 


\begin{tabular}{|c|c|c|c|c|c|c|c|c|c|c|c|c|c|}
\hline Sample & Unit & ${ }^{40} \mathrm{Ar} /{ }^{39} \mathrm{Ar}$ & +- & ${ }^{38} \mathrm{Ar} /{ }^{39} \mathrm{Ar}$ & +- & ${ }^{36} \mathrm{Ar} /{ }^{39} \mathrm{Ar}$ & +- & Total ${ }^{39} \mathrm{Ar}$ & +- & ${ }^{40} \mathrm{Ar} * /^{39} \mathrm{Ar}$ & +- & Age (Ma) & +- \\
\hline $80170 \mathrm{~ms}$ & EMC & 3.99523 & 0.02834 & 0.01883 & 0.00086 & 0.00243 & 0.00121 & 0.03699 & 0.00022 & 3.27616 & 0.35818 & 34.8 & 3.8 \\
\hline $80170 \mathrm{~ms}$ & & 4.93960 & 0.03200 & 0.01722 & 0.00071 & 0.00185 & 0.00053 & 0.05688 & 0.00025 & 4.39410 & 0.16090 & 46.6 & 1.7 \\
\hline $80170 \mathrm{~ms}$ & & 4.41024 & 0.05038 & 0.01658 & 0.00055 & 0.00138 & 0.00037 & 0.08309 & 0.00093 & 4.00125 & 0.11750 & 42.4 & 1.2 \\
\hline $80170 \mathrm{~ms}$ & & 4.44710 & 0.02786 & 0.01570 & 0.00036 & 0.00226 & 0.00031 & 0.10415 & 0.00058 & 3.78032 & 0.09411 & 40.1 & 1.0 \\
\hline $80170 \mathrm{~ms}$ & & 4.63429 & 0.04137 & 0.01711 & 0.00083 & 0.00176 & 0.00039 & 0.11355 & 0.00090 & 4.11384 & 0.12234 & 43.6 & 1.3 \\
\hline $80170 \mathrm{~ms}$ & & 4.09228 & 0.01626 & 0.01629 & 0.00038 & 0.00168 & 0.00034 & 0.14838 & 0.00041 & 3.59442 & 0.10269 & 38.2 & 1.1 \\
\hline $80170 \mathrm{~ms}$ & & 4.50727 & 0.02099 & 0.01735 & 0.00048 & 0.00165 & 0.00053 & 0.10617 & 0.00038 & 4.02020 & 0.15683 & 42.6 & 1.7 \\
\hline 80170 small ms & & 5.04530 & 0.04897 & 0.01592 & 0.00093 & 0.00237 & 0.00048 & 0.08211 & 0.00075 & 4.34350 & 0.14696 & 46.0 & 1.6 \\
\hline 80170 gnt & & 6.07988 & 0.05618 & 0.02565 & 0.00521 & 0.00498 & 0.00359 & 0.01003 & 0.00007 & 4.60750 & 1.06284 & 48.8 & 11.1 \\
\hline 80170 gnt & & 5.28873 & 0.02983 & 0.01594 & 0.00047 & 0.00189 & 0.00024 & 0.11623 & 0.00060 & 4.72942 & 0.07687 & 50.1 & 0.8 \\
\hline 80175 bte & GMC & 3.72464 & 0.02289 & 0.01237 & 0.00105 & 0.00243 & 0.00075 & 0.05347 & 0.00026 & 3.00618 & 0.22199 & 32.0 & 2.3 \\
\hline 80175 bte & & 3.31869 & 0.02896 & 0.01332 & 0.00033 & 0.00136 & 0.00056 & 0.06974 & 0.00039 & 2.91614 & 0.16776 & 31.0 & 1.8 \\
\hline 80175 bte & & 3.16973 & 0.02734 & 0.01248 & 0.00071 & 0.00132 & 0.00071 & 0.05702 & 0.00045 & 2.78102 & 0.21037 & 29.6 & 2.2 \\
\hline 80175 bte & & 3.79379 & 0.03858 & 0.01477 & 0.00060 & 0.00266 & 0.00078 & 0.10352 & 0.00091 & 3.00876 & 0.23291 & 32.0 & 2.5 \\
\hline 80175 bte & & 3.35609 & 0.03147 & 0.01287 & 0.00023 & 0.00093 & 0.00028 & 0.15024 & 0.00127 & 3.08073 & 0.08847 & 32.8 & 0.9 \\
\hline 80175 bte & & 4.05418 & 0.03201 & 0.01107 & 0.00042 & 0.00048 & 0.00015 & 0.13448 & 0.00083 & 3.91136 & 0.05507 & 41.5 & 0.6 \\
\hline 80175 bte & & 3.20208 & 0.03914 & 0.01158 & 0.00100 & 0.00047 & 0.00039 & 0.05272 & 0.00052 & 3.06196 & 0.12164 & 32.6 & 1.3 \\
\hline 80175 bte & & 3.84826 & 0.02765 & 0.01376 & 0.00069 & 0.00286 & 0.00046 & 0.08729 & 0.00036 & 3.00192 & 0.13786 & 31.9 & 1.5 \\
\hline $80175 \mathrm{~ms}$ & & 4.41954 & 0.03581 & 0.01207 & 0.00048 & 0.00093 & 0.00062 & 0.06482 & 0.00043 & 4.14603 & 0.18554 & 44.0 & 2.0 \\
\hline $80175 \mathrm{~ms}$ & & 4.08699 & 0.03350 & 0.01283 & 0.00069 & 0.00029 & 0.00074 & 0.08496 & 0.00039 & 4.00004 & 0.22042 & 42.4 & 2.3 \\
\hline $80175 \mathrm{~ms}$ & & 5.33215 & 0.04311 & 0.01141 & 0.00068 & 0.00071 & 0.00084 & 0.06328 & 0.00043 & 5.12202 & 0.25170 & 54.2 & 2.6 \\
\hline $80175 \mathrm{~ms}$ & & 4.55265 & 0.02277 & 0.01201 & 0.00030 & 0.00011 & 0.00023 & 0.13155 & 0.00047 & 4.51895 & 0.07199 & 47.9 & 0.8 \\
\hline $80175 \mathrm{~ms}$ & & 4.33802 & 0.04104 & 0.01294 & 0.00167 & 0.00080 & 0.00122 & 0.04368 & 0.00038 & 4.10124 & 0.36170 & 43.5 & 3.8 \\
\hline $80175 \mathrm{~ms}$ & & 5.12364 & 0.04513 & 0.01293 & 0.00097 & n.d. & n.d. & 0.04879 & 0.00035 & 5.48705 & 0.49061 & 58.0 & 5.1 \\
\hline $80175 \mathrm{~ms}$ & & 4.24715 & 0.02894 & 0.01195 & 0.00038 & n.d. & n.d. & 0.10345 & 0.00047 & 4.36141 & 0.14580 & 46.2 & 1.5 \\
\hline 80175 ms & & 4.93386 & 0.03354 & 0.01151 & 0.00062 & n.d. & n.d. & 0.07281 & 0.00037 & 5.05561 & 0.13276 & 53.5 & 1.4 \\
\hline 80175 ms t1 & & 3.64520 & 0.03149 & 0.01437 & 0.00218 & n.d. & n.d. & 0.01897 & 0.00011 & 4.50194 & 0.62893 & 47.7 & 6.6 \\
\hline 80175 ms t2 & & 3.68172 & 0.03713 & 0.01145 & 0.00130 & n.d. & n.d. & 0.04495 & 0.00034 & 3.81321 & 0.21133 & 40.5 & 2.2 \\
\hline 80175 ms t3 & & 3.78985 & 0.04359 & 0.01727 & 0.00194 & 0.00092 & 0.00153 & 0.01636 & 0.00016 & 3.51895 & 0.45338 & 37.4 & 4.8 \\
\hline 80175 ms t4 & & 4.42509 & 0.05497 & 0.01105 & 0.00107 & n.d. & n.d. & 0.03152 & 0.00037 & 4.94080 & 0.50204 & 52.3 & 5.2 \\
\hline 80175 ms & & 4.07501 & 0.03945 & 0.01225 & 0.00115 & 0.00011 & 0.00105 & 0.04696 & 0.00025 & 4.04355 & 0.31238 & 42.9 & 3.3 \\
\hline $80175 \mathrm{~ms}$ & & 4.55281 & 0.02720 & 0.01172 & 0.00058 & n.d. & n.d. & 0.12406 & 0.00068 & 4.69572 & 0.13127 & 49.7 & 1.4 \\
\hline 80175 feld & & 3.96940 & 0.02474 & 0.01276 & 0.00061 & 0.00048 & 0.00088 & 0.05261 & 0.00022 & 3.82898 & 0.26007 & 40.6 & 2.7 \\
\hline $80176 \mathrm{~ms}$ & GMC & 5.24455 & 0.04027 & 0.01340 & 0.00071 & n.d. & n.d. & 0.07231 & 0.00051 & 5.48973 & 0.17361 & 58.0 & 1.8 \\
\hline $80176 \mathrm{~ms}$ & & 4.77295 & 0.01739 & 0.01272 & 0.00046 & 0.00038 & 0.00027 & 0.14528 & 0.00043 & 4.66108 & 0.08125 & 49.4 & 0.9 \\
\hline $80176 \mathrm{~ms}$ & & 3.96046 & 0.01700 & 0.01170 & 0.00053 & 0.00010 & 0.00026 & 0.21013 & 0.00067 & 3.93233 & 0.07760 & 41.7 & 0.8 \\
\hline $80176 \mathrm{~ms}$ & & 3.96412 & 0.02681 & 0.01060 & 0.00096 & n.d. & n.d. & 0.08953 & 0.00047 & 4.07965 & 0.14362 & 43.3 & 1.5 \\
\hline 80176 bte & & 3.41002 & 0.02437 & 0.01160 & 0.00086 & 0.00021 & 0.00033 & 0.09442 & 0.00057 & 3.34743 & 0.10185 & 35.6 & 1.1 \\
\hline 80176 bte & & 3.06255 & 0.01728 & 0.01135 & 0.00043 & 0.00035 & 0.00019 & 0.15870 & 0.00060 & 2.96014 & 0.05913 & 31.5 & 0.6 \\
\hline 80176 bte & & 3.13694 & 0.01783 & 0.01235 & 0.00041 & 0.00098 & 0.00055 & 0.10215 & 0.00037 & 2.84765 & 0.16455 & 30.3 & 1.7 \\
\hline 80176 bte & & 3.61510 & 0.01650 & 0.01404 & 0.00076 & 0.00154 & 0.00106 & 0.09743 & 0.00028 & 3.16013 & 0.31267 & 33.6 & 3.3 \\
\hline 80176 bte & & 3.25654 & 0.01968 & 0.01307 & 0.00022 & 0.00146 & 0.00058 & 0.10968 & 0.00059 & 2.82549 & 0.17340 & 30.1 & 1.8 \\
\hline 80176 bte & & 3.42435 & 0.03205 & 0.01313 & 0.00085 & 0.00084 & 0.00099 & 0.05919 & 0.00037 & 3.17472 & 0.29276 & 33.8 & 3.1 \\
\hline 80176 bte & & 3.25219 & 0.02294 & 0.01261 & 0.00068 & 0.00113 & 0.00034 & 0.10608 & 0.00059 & 2.91792 & 0.10271 & 31.1 & 1.1 \\
\hline 80192 hb & GMC & 30.16781 & 1.47343 & 0.18019 & 0.03976 & 0.03433 & 0.03887 & 0.00146 & 0.00007 & 20.02459 & 11.52039 & 203.1 & 110.5 \\
\hline 80192 hb & & 30.73983 & 0.61868 & 0.13056 & 0.00724 & 0.00705 & 0.00645 & 0.00994 & 0.00020 & 28.65785 & 1.99047 & 284.0 & 18.3 \\
\hline 80192 hb & & 37.71370 & 0.67481 & 0.13905 & 0.00749 & 0.00044 & 0.00441 & 0.01140 & 0.00020 & 37.58408 & 1.46607 & 364.1 & 13.0 \\
\hline 80192 hb & & 33.22591 & 0.57958 & 0.08016 & 0.00402 & 0.00828 & 0.00169 & 0.01329 & 0.00023 & 30.77942 & 0.73297 & 303.4 & 6.8 \\
\hline 80192 hb next to feld & & 13.58090 & 0.50263 & 0.06923 & 0.01252 & n.d. & n.d. & 0.00168 & 0.00006 & 18.86767 & 11.84054 & 191.9 & 114.3 \\
\hline 80192 edge & & 23.42198 & 0.44251 & 0.11171 & 0.00658 & 0.00903 & 0.00404 & 0.01107 & 0.00020 & 20.75264 & 1.25857 & 210.1 & 12.1 \\
\hline 80192 edge 2 & & 35.18583 & 0.45592 & 0.13023 & 0.00632 & 0.00457 & 0.00727 & 0.00984 & 0.00013 & 33.83508 & 2.19324 & 330.9 & 19.7 \\
\hline 80192 edge 3 & & 25.82589 & 0.45264 & 0.11345 & 0.00451 & 0.00204 & 0.00401 & 0.01228 & 0.00021 & 25.22429 & 1.26500 & 252.3 & 11.9 \\
\hline 80192 edge 4 & & 11.93210 & 0.16592 & 0.05154 & 0.00337 & n.d. & n.d. & 0.01351 & 0.00017 & 12.36942 & 0.89119 & 128.1 & 8.9 \\
\hline 80192 edge 5 & & 16.05060 & 0.22330 & 0.10517 & 0.00388 & 0.00226 & 0.00187 & 0.01104 & 0.00014 & 15.38134 & 0.59230 & 158.0 & 5.9 \\
\hline 80192 edge 6 & & 10.82884 & 0.16162 & 0.05030 & 0.00242 & 0.00332 & 0.00149 & 0.02258 & 0.00032 & 9.84722 & 0.46333 & 102.7 & 4.7 \\
\hline $80192 ?$ (t2 1?) & & 28.84907 & 0.93257 & 0.02602 & 0.01697 & 0.00152 & 0.01295 & 0.00330 & 0.00010 & 28.40110 & 3.93614 & 281.7 & 36.2 \\
\hline 80192 t2 2 & & 30.21580 & 0.73966 & 0.17222 & 0.01395 & n.d. & n.d. & 0.00645 & 0.00015 & 30.44495 & 1.99202 & 300.4 & 18.2 \\
\hline $80192 ?$ (t2 3?) & & 28.71597 & 0.62347 & 0.23257 & 0.01201 & 0.01903 & 0.00894 & 0.00762 & 0.00016 & 23.09124 & 2.68582 & 232.3 & 25.4 \\
\hline 80192 tr amp 1 & & 11.95974 & 0.16249 & 0.06229 & 0.00502 & 0.00346 & 0.00671 & 0.01013 & 0.00013 & 10.93872 & 1.98961 & 113.8 & 20.1 \\
\hline 80192 tr amp 2 & & 16.07842 & 0.28965 & 0.09195 & 0.00649 & 0.00561 & 0.00337 & 0.01070 & 0.00019 & 14.42197 & 1.02904 & 148.5 & 10.2 \\
\hline 80192 tr amp 3 & & 31.05644 & 0.51432 & 0.20708 & 0.01215 & 0.01424 & 0.00550 & 0.00773 & 0.00013 & 26.84955 & 1.68292 & 267.4 & 15.6 \\
\hline 80192 tr amp 4 & & 17.89668 & 0.55605 & 0.13048 & 0.01335 & 0.02311 & 0.00434 & 0.00584 & 0.00018 & 11.06717 & 1.31125 & 115.1 & 13.2 \\
\hline 80192 tr amp/feld 5 & & 14.41504 & 0.26537 & 0.04698 & 0.01661 & 0.01045 & 0.00692 & 0.00526 & 0.00010 & 11.32782 & 2.05407 & 117.7 & 20.7 \\
\hline 80192 feld & & 9.96530 & 0.14817 & 0.03225 & 0.00372 & 0.00163 & 0.00301 & 0.01534 & 0.00022 & 9.48360 & 0.89942 & 99.0 & 9.2 \\
\hline 80192 feld & & 10.82507 & 0.15881 & 0.02263 & 0.00427 & 0.00350 & 0.00210 & 0.01428 & 0.00020 & 9.79024 & 0.63749 & 102.1 & 6.5 \\
\hline 80192 tr feld 1 & & 12.57704 & 0.16010 & 0.05808 & 0.00278 & 0.00446 & 0.00399 & 0.01121 & 0.00012 & 11.25902 & 1.18817 & 117.0 & 12.0 \\
\hline
\end{tabular}

Volume of total ${ }^{39}$ Ar measured = 'value' $\times 10^{-12} \mathrm{~cm}^{3}$ STP

Reactor: Ford Reactor, Michigan, USA

J Value: 0.00605

n.d. $=$ not determined 


\begin{tabular}{|c|c|c|c|c|c|}
\hline Sample & Unit & ${ }^{40} \mathrm{Ar} /{ }^{39} \mathrm{Ar}$ & + & ${ }^{38} \mathrm{Ar}{ }^{39} \mathrm{Ar}$ & + \\
\hline J3-27 amp 1a & GMC & 38.18539 & 2.63154 & 0.27230 & 0.02077 \\
\hline J3-27amp 1b & & 48.95624 & 1.31300 & 0.44008 & 0.02222 \\
\hline J3-27 amp 2a & & 67.88521 & 2.38315 & 1.03459 & 0.03810 \\
\hline J3-27 amp 2b & & 67.78800 & 2.68033 & 1.02779 & 0.04437 \\
\hline J3-27 amp 2c & & 53.50674 & 2.40831 & 0.85377 & 0.04125 \\
\hline J3-35 bte 1a & VP & 19.66845 & 0.13826 & 0.10561 & 0.00196 \\
\hline J3-35 bte $1 \mathrm{~b}$ & & 18.08495 & 0.11652 & 0.09062 & 0.00152 \\
\hline J3-35 bte 1c & & 19.55334 & 0.13956 & 0.08984 & 0.00179 \\
\hline J3-35 bte 2a & & 15.94026 & 0.08484 & 0.10913 & 0.00152 \\
\hline J3-35 bte $2 b$ & & 24.22696 & 0.19298 & 0.13836 & 0.00390 \\
\hline J3-35 bte 3a & & 13.82908 & 0.27706 & 0.09002 & 0.00485 \\
\hline J3-35 bte 3b & & 29.90134 & 0.25626 & 0.13580 & 0.00126 \\
\hline J3-35 bte 3c & & 12.61553 & 0.14091 & 0.09774 & 0.00290 \\
\hline J3-35 bte 4 & & 15.52678 & 0.14808 & 0.10680 & 0.00213 \\
\hline J3-35 bte 5 & & 14.47406 & 0.81387 & 0.21558 & 0.02204 \\
\hline J3-35 bte trav 1a & & 37.98043 & 5.46575 & 0.35670 & 0.07216 \\
\hline J3-35 bte trav 1b & & 21.73116 & 2.47179 & 0.18873 & 0.04240 \\
\hline J3-35 bte trav 1c & & 38.07612 & 4.58209 & 0.41600 & 0.05588 \\
\hline J3-35 bte trav 1d & & 41.62438 & 3.76530 & 0.39857 & 0.04196 \\
\hline J3-35 bte trav 1e & & 29.13196 & 3.25765 & 0.31173 & 0.03712 \\
\hline J3-35 bte trav if & & 16.05038 & 1.57348 & 0.22428 & 0.02570 \\
\hline J3-35 bte trav 1g & & 14.61088 & 0.62919 & 0.10567 & 0.00775 \\
\hline J3-35 bte trav 2a & & 147.26184 & 98.20373 & 0.58886 & 0.41597 \\
\hline J3-35 bte trav 2b & & 40.35305 & 4.49082 & 0.20710 & 0.02853 \\
\hline J3-35 bte trav 2c & & 16.67491 & 0.32026 & 0.11264 & 0.00648 \\
\hline J3-35 bte trav 2d & & 23.52280 & 0.87312 & 0.16534 & 0.00836 \\
\hline J3-35 bte trav 2e & & 18.40557 & 0.29119 & 0.11176 & 0.00338 \\
\hline J3-35 bte trav 2g & & 18.46737 & 0.35907 & 0.10778 & 0.00478 \\
\hline J3-35 bte trav 2f & & 18.13200 & 0.43865 & 0.11659 & 0.00374 \\
\hline J3-35 fsp 1a & & 19.04871 & 0.24329 & 0.06764 & 0.00475 \\
\hline J3-35 fsp 1b & & 136.52887 & 1.74926 & 0.26959 & 0.00942 \\
\hline J3-35 fsp 2 & & 138.29984 & 2.36240 & 0.46363 & 0.01047 \\
\hline s3-74 wm & Combin & 9.33288 & 0.23264 & 0.02537 & 0.00406 \\
\hline S3-74 wm 1 & & 5.36863 & 0.06643 & 0.01902 & 0.00198 \\
\hline S3-74 wm 2 & & 4.08088 & 0.04239 & 0.01632 & 0.00097 \\
\hline S3-74 wm 3 & & 33.31798 & 3.05287 & 0.12627 & 0.01498 \\
\hline S3-74 wm 4 & & 4.03200 & 0.04833 & 0.01544 & 0.00099 \\
\hline S3-74 wm 5a & & 25.22981 & 2.89166 & 0.32085 & 0.07279 \\
\hline S3-74 wm 5b & & 15.39394 & 0.64523 & 0.16606 & 0.01421 \\
\hline S3-74 wm 6 & & 4.70178 & 0.04654 & 0.02319 & 0.00085 \\
\hline S3-74 wm 7 & & 5.45565 & 0.05615 & 0.02345 & 0.00220 \\
\hline S3-74 wm 8 & & 5.72543 & 0.04523 & 0.01874 & 0.00097 \\
\hline S3-74 qtz 1 & & 60.37817 & 1.78835 & 0.09064 & 0.00813 \\
\hline S3-74 cc 1 & & 249.20098 & 37.81203 & 0.42766 & 0.06905 \\
\hline S3-24 wm 1 & CO basement & 3.65398 & 0.01835 & 0.01326 & 0.00033 \\
\hline S3-24 wm 2 & & 3.51458 & 0.04225 & 0.01244 & 0.00039 \\
\hline S3-24 wm 3a & & 3.57824 & 0.05290 & 0.01325 & 0.00070 \\
\hline S3-24 wm 3b & & 3.32519 & 0.05532 & 0.01321 & 0.00031 \\
\hline S3-24 wm 3c & & 3.26372 & 0.05282 & 0.01366 & 0.00055 \\
\hline S3-24 wm 3d & & 3.42952 & 0.05506 & 0.01385 & 0.00099 \\
\hline S3-24 wm 4a & & 3.69398 & 0.05506 & 0.01239 & 0.00200 \\
\hline S3-24 wm 4b & & 3.46632 & 0.05118 & 0.01606 & 0.00179 \\
\hline S3-24 wm 5 & & 3.39178 & 0.04467 & 0.01254 & 0.00052 \\
\hline S3-24 wm 6 & & 3.35400 & 0.04800 & 0.01317 & 0.00074 \\
\hline S3-72 wm 1 & MR & 4.19697 & 0.02468 & 0.01406 & 0.00060 \\
\hline S3-72 wm 2 & & 4.13234 & 0.02012 & 0.01393 & 0.00050 \\
\hline S3-72 wm 3a & & 11.40220 & 0.09902 & 0.01403 & 0.00036 \\
\hline S3-72 wm 3b & & 11.96268 & 0.08641 & 0.01447 & 0.00040 \\
\hline S3-72 wm 3c & & 9.56223 & 0.09438 & 0.01432 & 0.00063 \\
\hline S3-72 wm 3d & & 9.12186 & 0.05570 & 0.01467 & 0.00043 \\
\hline S3-72 wm 3e & & 5.28025 & 0.04452 & 0.01521 & 0.00050 \\
\hline S3-72 wm 3f & & 4.67216 & 0.06729 & 0.01559 & 0.00090 \\
\hline S3-72 wm 3g & & 9.45010 & 0.16410 & 0.01721 & 0.00134 \\
\hline S3-72 wm 4 & & 4.46538 & 0.07072 & 0.01524 & 0.00177 \\
\hline S3-72 wm 5 & & 5.06695 & 0.06769 & 0.01923 & 0.00091 \\
\hline S3-72 wm 6a & & 5.11443 & 0.08730 & 0.02912 & 0.00311 \\
\hline S3-72 wm 6b & & 6.25530 & 0.28632 & 0.03096 & 0.00838 \\
\hline S3-72 wm 6c & & 5.30479 & 0.03534 & 0.01866 & 0.00106 \\
\hline S3-72 wm 6d & & 6.11687 & 0.27139 & 0.04826 & 0.00332 \\
\hline S3-72 wm 6e & & 4.89347 & 0.03053 & 0.01760 & 0.00097 \\
\hline S3-72wm trav 7a & & 11.48495 & 0.12535 & 0.02027 & 0.00116 \\
\hline S3-72wm trav 7b & & 9.11440 & 0.14185 & 0.02140 & 0.00126 \\
\hline S3-72wm trav 7c & & 12.56463 & 0.23830 & 0.02158 & 0.00144 \\
\hline S3-72wm trav 7d & & 7.23001 & 0.15678 & 0.02133 & 0.00196 \\
\hline S3-72wm trav 7e & & 6.23022 & 0.05916 & 0.01438 & 0.00157 \\
\hline S3-72wm trav 7f & & 7.30936 & 0.12325 & 0.01469 & 0.00190 \\
\hline S3-72wm trav $7 g$ & & 8.44099 & 0.09100 & 0.02086 & 0.00217 \\
\hline S3-72wm trav 7h & & 3.62446 & 0.07112 & 0.02090 & 0.00396 \\
\hline S3-72wm trav 7i & & 4.47505 & 0.15292 & 0.03299 & 0.00403 \\
\hline S3-72 wm trav 8a & & 3.96519 & 0.05496 & 0.01551 & 0.00137 \\
\hline S3-72 wm trav 8b & & 3.87712 & 0.15893 & 0.01413 & 0.00090 \\
\hline S3-72 wm trav 8c & & 4.16694 & 0.04721 & 0.01654 & 0.00124 \\
\hline S3-72 wm trav 8d & & 7.13876 & 0.17179 & 0.01615 & 0.00237 \\
\hline S3-72 wm trav 8e & & 5.45491 & 0.10530 & 0.01583 & 0.00162 \\
\hline S3-72 wm trav 8f & & 3.97905 & 0.07502 & 0.01736 & 0.00220 \\
\hline S3-72 wm trav 8g & & 4.23468 & 0.09439 & 0.02011 & 0.00288 \\
\hline qtz 1 & & 13.30297 & 0.61803 & 0.04782 & 0.00614 \\
\hline qtz 2a & & 52.80342 & 9.85560 & 0.10390 & 0.04933 \\
\hline$q \operatorname{qz} 2 b$ & & 107.28697 & 17.81296 & 0.01892 & 0.05425 \\
\hline qtz $3 a$ & & 110.94105 & 32.69865 & 0.21757 & 0.07716 \\
\hline qtz $3 b$ & & 547.98712 & 469.85958 & 0.45255 & 0.42746 \\
\hline gnt 1 & & 29.38365 & 18.95544 & 1.07171 & 0.70085 \\
\hline
\end{tabular}

Volume of total ${ }^{39} \mathrm{Ar}$ measured = 'value' $\times 10^{-10} \mathrm{~cm}^{3}$ STP

Reactor: Ford Reactor, Michigan, USA.

$\mathrm{J}$ value: $\mathbf{0 . 0 0 6 4}$

n.d. = not determined 


\begin{tabular}{|c|c|c|c|c|c|c|c|c|c|c|c|c|c|c|c|}
\hline Sample & Unit & ${ }^{40} \mathrm{Ar} /{ }^{39} \mathrm{Ar}$ & +- & ${ }^{38} \mathrm{Ar} /{ }^{39} \mathrm{Ar}$ & +- & ${ }^{37} \mathrm{Ar} /{ }^{39} \mathrm{Ar}$ & +- & ${ }^{36} \mathrm{Ar} /{ }^{39} \mathrm{Ar}$ & + & Total ${ }^{39} \mathrm{Ar}$ & +- & ${ }^{40} \mathrm{Ar} * /^{39} \mathrm{Ar}$ & +- & Age (Ma) & +- \\
\hline s4-12a bte1 & Dyke & 4.88407 & 0.10420 & 0.01223 & 0.00072 & 0.03355 & 0.22259 & 0.00065 & 0.00033 & 0.03050 & 0.00059 & 4.69286 & 0.13986 & 35.6 & 1.1 \\
\hline s4-12a bte 2 & & 5.55523 & 0.10907 & 0.01206 & 0.00059 & 0.65109 & 0.18037 & 0.00116 & 0.00053 & 0.03771 & 0.00067 & 5.21348 & 0.18786 & 39.5 & 1.4 \\
\hline s4-12a bte 3 & & 5.37164 & 0.07948 & 0.01413 & 0.00032 & 0.77547 & 0.20208 & 0.00126 & 0.00048 & 0.03760 & 0.00048 & 4.99899 & 0.16049 & 37.9 & 1.2 \\
\hline s4-12a bte 4 & & 7.41788 & 0.11635 & 0.01244 & 0.00036 & 0.38996 & 0.18587 & 0.00279 & 0.00055 & 0.03286 & 0.00050 & 6.59354 & 0.19273 & 49.9 & 1.5 \\
\hline s4-12a bte 5 & & 5.03627 & 0.13494 & 0.01317 & 0.00104 & 0.38708 & 0.30646 & 0.00256 & 0.00100 & 0.02251 & 0.00054 & 4.27840 & 0.31670 & 32.5 & 2.4 \\
\hline s4-12a bte 6 & & 5.50719 & 0.11618 & 0.01302 & 0.00046 & 0.30903 & 0.11886 & 0.00167 & 0.00028 & 0.05142 & 0.00093 & 5.01371 & 0.13567 & 38.0 & 1.0 \\
\hline s4-12a bte 7 & & 6.75937 & 0.17190 & 0.01445 & 0.00075 & 0.47232 & 0.09299 & 0.00226 & 0.00036 & 0.08808 & 0.00186 & 6.09110 & 0.19229 & 46.1 & 1.5 \\
\hline s4-41 wm 1 & Combin & 5.59222 & 0.10261 & 0.01229 & 0.00049 & 0.06512 & 0.12145 & 0.00119 & 0.00028 & 0.04991 & 0.00084 & 5.24200 & 0.12832 & 39.8 & 1.0 \\
\hline s4-41 wm 2 & & 5.98664 & 0.17805 & 0.01284 & 0.00053 & 0.01389 & 0.08795 & 0.00230 & 0.00019 & 0.07802 & 0.00209 & 5.30592 & 0.17045 & 40.2 & 1.3 \\
\hline s4-41 wm 3 & & 5.71790 & 0.15114 & 0.01260 & 0.00058 & 0.10199 & 0.18187 & 0.00068 & 0.00024 & 0.04258 & 0.00106 & 5.51752 & 0.16207 & 41.8 & 1.2 \\
\hline s4-41 wm 4 & & 5.96323 & 0.10573 & 0.01278 & 0.00075 & 0.41755 & 0.53764 & 0.00117 & 0.00064 & 0.01560 & 0.00027 & 5.61649 & 0.21413 & 42.6 & 1.6 \\
\hline s4-41 wm 6 & & 6.09602 & 0.23943 & 0.01258 & 0.00097 & n.d. & n.d. & 0.00094 & 0.00059 & 0.02397 & 0.00084 & 5.81805 & 0.28923 & 44.1 & 2.2 \\
\hline s4-41 wm 7 & & 5.85256 & 0.21701 & 0.01210 & 0.00075 & 0.04138 & 0.05626 & 0.00062 & 0.00018 & 0.07898 & 0.00254 & 5.66865 & 0.21840 & 42.9 & 1.6 \\
\hline s4-14 wm 1 & Z. Saas & 57.21135 & 1.45362 & 0.01598 & 0.00211 & 36.24839 & 2.51813 & 0.00778 & 0.00261 & 0.00959 & 0.00019 & 54.91321 & 1.61264 & 378.4 & 10.2 \\
\hline s4-14 wm 2 & & 19.47892 & 0.67073 & 0.01431 & 0.00301 & n.d. & n.d. & 0.00744 & 0.00600 & 0.00607 & 0.00020 & 17.28159 & 1.87133 & 127.9 & 13.4 \\
\hline s4-14 wm 3 & & 17.88864 & 0.53371 & 0.01556 & 0.00209 & 3.83569 & 1.41524 & 0.00600 & 0.00300 & 0.01215 & 0.00031 & 16.11681 & 1.01427 & 119.5 & 7.3 \\
\hline s4-14 wm 4 & & 17.54270 & 0.41138 & 0.01246 & 0.00223 & 1.56800 & 1.10387 & 0.00181 & 0.00157 & 0.00902 & 0.00019 & 17.00796 & 0.61293 & 125.9 & 4.4 \\
\hline s4-14 wm 5 & & 10.72659 & 0.33629 & 0.01560 & 0.00306 & n.d. & n.d. & 0.00615 & 0.00432 & 0.00328 & 0.00005 & 8.90992 & 1.31631 & 67.1 & 9.7 \\
\hline s4-14 wm 6 & & 62.37113 & 1.94289 & 0.02494 & 0.00304 & 28.92386 & 2.33973 & 0.03652 & 0.00513 & 0.00840 & 0.00021 & 51.58008 & 2.28763 & 357.6 & 14.5 \\
\hline s4-14 wm 7 & & 100.69472 & 3.31235 & 0.02757 & 0.00575 & 24.48594 & 3.00648 & 0.03489 & 0.01146 & 0.00315 & 0.00006 & 90.38461 & 4.65729 & 586.5 & 25.9 \\
\hline s4-3a wm1 & Z. Saas & 6.27892 & 0.18276 & 0.01320 & 0.00098 & n.d. & n.d. & 0.00036 & 0.00095 & 0.02168 & 0.00056 & 6.17162 & 0.33389 & 46.7 & 2.5 \\
\hline s4-3a wm2 & & 5.56192 & 0.19069 & 0.01751 & 0.00249 & n.d. & n.d. & 0.00126 & 0.00274 & 0.00409 & 0.00010 & 5.19046 & 0.82920 & 39.4 & 6.2 \\
\hline s4-3a wm 3a & & 6.61094 & 0.22427 & 0.01400 & 0.00088 & n.d. & n.d. & 0.00153 & 0.00108 & 0.01314 & 0.00042 & 6.15812 & 0.38145 & 46.6 & 2.9 \\
\hline s4-3a wm 3b & & 6.41431 & 0.22494 & 0.01229 & 0.00066 & 0.04707 & 0.09359 & 0.00087 & 0.00040 & 0.05653 & 0.00183 & 6.15657 & 0.24671 & 46.6 & 1.9 \\
\hline s4-3a wm3c & & 6.14718 & 0.20402 & 0.01314 & 0.00052 & n.d. & n.d. & n.d. & n.d. & 0.02956 & 0.00089 & 6.19439 & 0.23375 & 46.9 & 1.8 \\
\hline s4-3a wm 4 & & 5.41652 & 0.17126 & 0.01178 & 0.00079 & 0.15334 & 0.09124 & 0.00080 & 0.00027 & 0.04165 & 0.00118 & 5.17996 & 0.18333 & 39.3 & 1.4 \\
\hline s4-3a wm 5 & & 7.70484 & 0.18085 & 0.01325 & 0.00225 & 0.42535 & 1.33042 & 0.00787 & 0.00282 & 0.00501 & 0.00010 & 5.38031 & 0.84566 & 40.8 & 6.3 \\
\hline s4-3a wm 5b & & 4.91792 & 0.10742 & 0.01401 & 0.00107 & n.d. & n.d. & 0.00057 & 0.00071 & 0.02006 & 0.00041 & 4.75020 & 0.23293 & 36.1 & 1.8 \\
\hline s4-3a wm 6 & & 7.85053 & 0.20549 & 0.01632 & 0.00119 & 0.18983 & 0.65342 & 0.00679 & 0.00115 & 0.00877 & 0.00019 & 5.84348 & 0.37791 & 44.3 & 2.8 \\
\hline s4-3a wm 7 & & 5.57733 & 0.10779 & 0.01240 & 0.00051 & 0.19368 & 0.08703 & 0.00086 & 0.00015 & 0.06594 & 0.00122 & 5.32332 & 0.11260 & 40.4 & 0.9 \\
\hline s4-3a wm 8 & & 5.74292 & 0.16699 & 0.01450 & 0.00337 & n.d. & n.d. & 0.00264 & 0.00335 & 0.00423 & 0.00011 & 4.96331 & 0.99946 & 37.7 & 7.5 \\
\hline s4-3c wm 1 & Z. Saas & 8.93322 & 0.20639 & 0.01491 & 0.00074 & 4.82704 & 0.64941 & 0.00768 & 0.00134 & 0.01679 & 0.00037 & 6.66425 & 0.42458 & 50.4 & 3.2 \\
\hline s4-3c wm2a & & 6.22107 & 0.12237 & 0.01323 & 0.00110 & 1.02425 & 0.64099 & 0.00453 & 0.00136 & 0.01043 & 0.00019 & 4.88352 & 0.41292 & 37.1 & 3.1 \\
\hline s4-3c wm 2b & & 6.19953 & 0.12390 & 0.01234 & 0.00081 & 1.10558 & 0.26786 & 0.00191 & 0.00032 & 0.03189 & 0.00056 & 5.63594 & 0.14791 & 42.7 & 1.1 \\
\hline s4-3c wm 2c & & 5.72342 & 0.13254 & 0.01294 & 0.00092 & 0.26532 & 0.21644 & 0.00192 & 0.00050 & 0.02014 & 0.00034 & 5.15683 & 0.19324 & 39.1 & 1.5 \\
\hline s4-3c wm 2d & & 5.56995 & 0.16250 & 0.01212 & 0.00082 & 0.10161 & 0.17768 & 0.00057 & 0.00027 & 0.04215 & 0.00112 & 5.40248 & 0.17678 & 41.0 & 1.3 \\
\hline s4-3c wm 3 & & 5.29315 & 0.16459 & 0.01143 & 0.00100 & n.d. & n.d. & 0.00155 & 0.00048 & 0.02325 & 0.00058 & 4.83412 & 0.21069 & 36.7 & 1.6 \\
\hline s4-3c wm 4 & & 4.92686 & 0.13059 & 0.01187 & 0.00052 & 0.29630 & 0.08758 & 0.00006 & 0.00019 & 0.07408 & 0.00189 & 4.90974 & 0.14187 & 37.3 & 1.1 \\
\hline s4-3c wm 5 & & 5.42684 & 0.10429 & 0.01133 & 0.00139 & 0.16488 & 0.34673 & 0.00119 & 0.00087 & 0.01623 & 0.00029 & 5.07546 & 0.27562 & 38.5 & 2.1 \\
\hline $85050 \mathrm{wm} 1$ & Z. Saas & 5.93609 & 0.18227 & 0.01069 & 0.00050 & 0.28926 & 0.22132 & 0.00113 & 0.00040 & 0.02485 & 0.00069 & 5.60160 & 0.21068 & 42.4 & 1.6 \\
\hline 85050 wm2 & & 6.36513 & 0.14360 & 0.01188 & 0.00031 & 0.26798 & 0.10669 & 0.00090 & 0.00019 & 0.05161 & 0.00105 & 6.09941 & 0.15009 & 46.2 & 1.1 \\
\hline 85050 wm3 & & 7.52469 & 0.19241 & 0.01316 & 0.00092 & 0.25700 & 0.14627 & 0.00447 & 0.00045 & 0.04739 & 0.00108 & 6.20371 & 0.21006 & 47.0 & 1.6 \\
\hline 85050 wm 4 & & 5.68104 & 0.17261 & 0.01357 & 0.00191 & 0.58804 & 0.78318 & 0.00051 & 0.00148 & 0.00753 & 0.00020 & 5.53010 & 0.47002 & 41.9 & 3.5 \\
\hline 85050 wm5 & & 7.62912 & 0.24190 & 0.01270 & 0.00085 & 0.53942 & 0.11668 & 0.00306 & 0.00053 & 0.03904 & 0.00105 & 6.72437 & 0.27106 & 50.8 & 2.0 \\
\hline $85050 \mathrm{wm} 6$ & & 6.95465 & 0.22446 & 0.01252 & 0.00107 & 1.40823 & 0.60647 & 0.00281 & 0.00102 & 0.01102 & 0.00031 & 6.12461 & 0.36280 & 46.4 & 2.7 \\
\hline
\end{tabular}

${ }^{39} \mathrm{Ar}$ measured = 'value' x $10^{-12} \mathrm{~cm}^{3} \mathrm{STP}$

Reactor: TRIGA, Oregon State University, USA

J Value: $\mathbf{0 . 0 0 4 2 5}$

n.d. $=$ not determined 


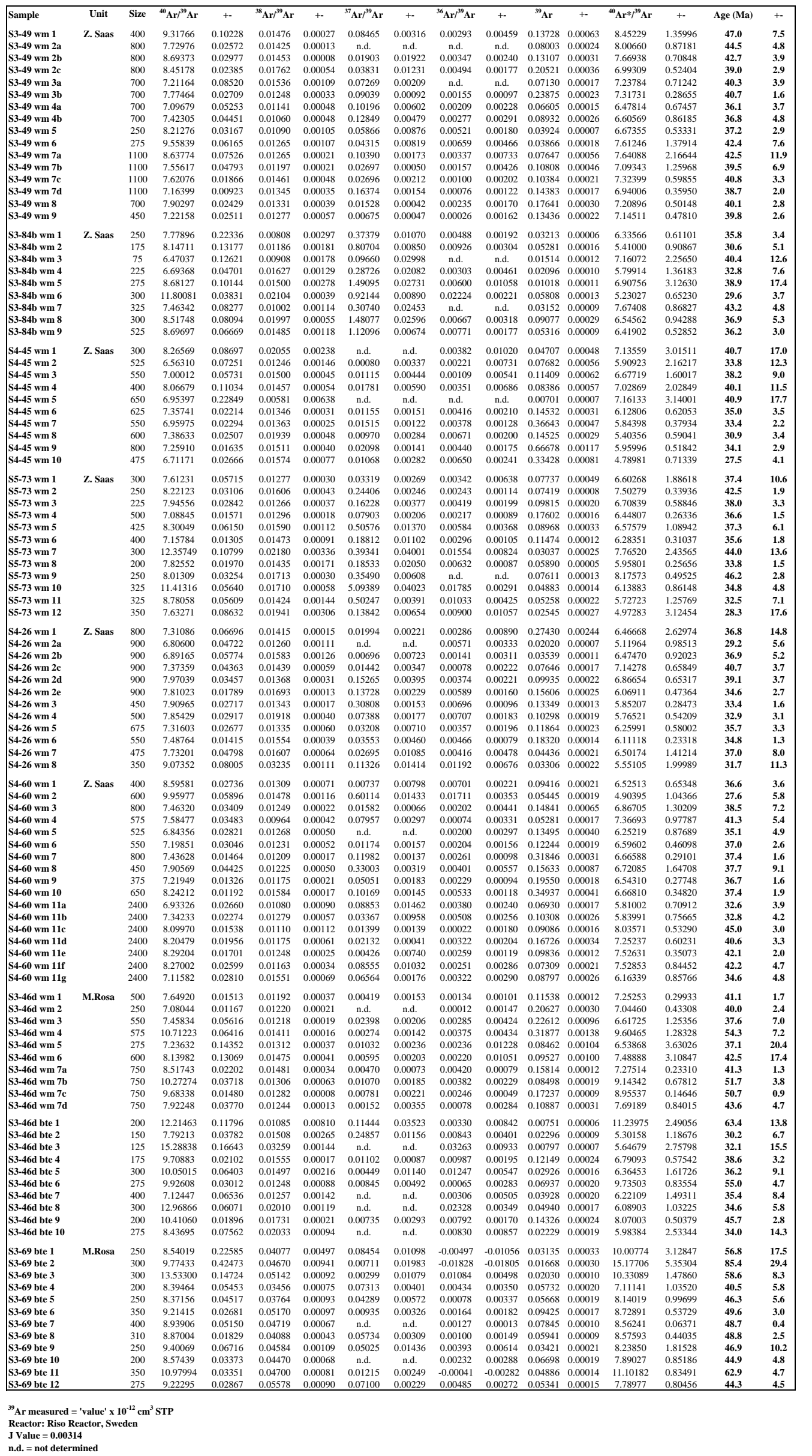

